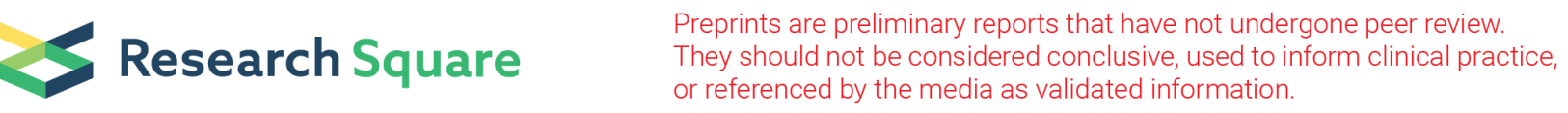

\title{
Phenotypic Differences Among and Within Extant Populations of Chrysanthemum Arcticum L. and C. a. Subsp. Arcticum
}

\section{Yunjia Liu}

University of Minnesota Twin Cities Campus: University of Minnesota

Neil 0 Anderson ( $\nabla$ ander044@umn.edu )

University of Minnesota Twin Cities Campus: University of Minnesota https://orcid.org/0000-00019794-0397

\section{Research article}

Keywords: plant morphology, population structure, salt tolerance, principal component analysis (PCoA), diagnostic traits

Posted Date: December 15th, 2020

DOI: https://doi.org/10.21203/rs.3.rs-126639/v1

License: (c) (i) This work is licensed under a Creative Commons Attribution 4.0 International License. Read Full License 


\section{Abstract}

Background. Chrysanthemum arcticum, Arctic daisy and its two subspecies (C. arcticum subsp. arcticum, C. arcticum subsp. polare) are the only chrysanthemum species native to North America. A study on species' variation in morphological and diagnostic traits is important to link morphological traits with previously described single nucleotide polymorphism (SNP) markers, particularly when the genomes are sequenced. The purpose of this study was to establish phenotypic differences and soil conditions among wild $C$. arcticum and $C$. a. subsp. arcticum populations, when grown in a uniform environment, for potential linkages with our SNP library. Sixteen quantitative morphological traits and five qualitative morphological traits were investigated for 255 individuals from nine $C$. arcticum populations and 326 individuals from 21 C. a. subsp. arcticum populations.

Results. While $100 \%$ of the $C$. a. subsp. arcticum individuals flowered under long days, $0 \%$ of the $C$. arcticum individuals flowered in 2018 while only $2.7 \%$ flowered in 2019. Two distinct clusters, distributed by taxonomic classification, were detected by Principal component analysis (PCoA) for 551 individuals from $C$. arcticum and $C$. a. subsp. arcticum. Pearson's correlation coefficient analysis indicated a positive and significant correlation between plant height, flower fresh and dry weights. Flower fresh weights were correlated with $\Delta$ flower weight, while inflorescence length had showed a negative correlation with leaf number. Soil samples had high Na levels along with heavy metals. Thus, the species are salt-tolerant.

Conclusion. A high level of salt tolerance $(\mathrm{Na})$ is tolerated by these maritime species which is a unique trait in Chrysanthemum. A new diagnostic trait of inflorescence length was discovered to distinguish among $C$. arcticum and $C$. a. subsp. arcticum. Significant flowering differences occurred among the species wherein $C$. a. subsp. arcticum had $100 \%$ flowering in long days whereas $C$. arcticum had $0 \%$ to $3.1 \%$. The mean number of weeks to visible bud date in $C$. a. subsp. arcticum is the fastest ( $2.2 \mathrm{wks}$.) ever reported in Chrysanthemum, in contrast with $C$. arcticum which is the longest (65.3-69.4 wks.). This study on the species' variation in morphological and diagnostic traits is of importance to link morphological traits with single nucleotide polymorphism (SNP) markers.

\section{Background}

Chrysanthemum arcticum L., Arctic daisy (= Arctanthemum arcticum; $=$ Dendranthema arcticum) and its two subspecies ( $C$. arcticum subsp. arcticum, $C$. arcticum subsp. polaré Hultén), hereafter collectively termed the "Chrysanthemum arcticum species complex", are the only chrysanthemum species native to North America [1, 2] with the center of origin and diversity in the State of Alaska (USA) and are also distributed throughout much of the maritime coastlines of Canada. Both $C$. arcticum and $C$. arcticum subsp. polaré are only found in the N. American mainland (from Alaska south and eastward in Canadian provinces), whereas $C$. arcticum subsp. arcticum, occurring both on the western Alaskan coastal mainland as well as sporadically throughout the Aleutian Islands, has two remnant populations occurring in Eurasia in the Kamchatka Peninsula (Russian Federation) and Hokkaido, Japan. 
Due to taxonomic name changes and the unique position of this $C$. arcticum species complex as an evolutionary remnant from the Eurasian center of origin and diversity for the Chrysanthemum genus [36], comparative studies with other members of the genus are of great interest, particularly given the salttolerant nature of these N. American species. Taxa within the Chrysanthemum arcticum species complex share many phenotypic traits, although species-specific diagnostic traits (primarily qualitative) in the dichotomous keys inherently differentiate them $[1,7]$. Leaves from both the species and subspecies are tripartite with primarily regularly toothed leaf margins whereas $C$. arcticum leaves tend to have a few more five-segmented leaves and a deep sinus. Chrysanthemum a. subsp. arcticum has leaves with a finely shallow sinus [8]. The number of midveins in the ray floret petals also differs among the species and subspecies $[1,7]$. Some quantitative differentiation of the taxa within the $C$. arcticum species complex also distinguish the subspecies, e.g. C. a. subsp. arcticum plants are $10-40 \mathrm{~cm}$ tall whereas $C$. a. subsp. polaré has the shortest stems of (2.5)5-20(-26) $\mathrm{cm}[7,9-11]$. Plant height for $C$. arcticum has not been reported $[1,7,12]$. In all instances, however, these quantitative measurements, which are highly affected by factors of plant growth $[13,14]$, were not performed with individuals growing in a uniform environment.

Plant structure, flower and leaf architecture influence $C . \times$ grandiflorum and $C . \times$ hybridum selection and breeding for important phenotypic traits, including plant height, photoperiodic response and flower color/type $[15,16]$. There are studies using multivariate analysis methods for identification within the species and populations via the morphological characteristics of the plant, including qualitative and quantitative data $[17,18]$. As winter-hardy herbaceous perennials, members of the Chrysanthemum arcticum species complex possess advantageous phenotypic traits that do not occur in the common chrysanthemum cultivars, such as salt tolerance (growing only in coastal, maritime habitats) and a ground-cover plant habit. Unique phenotypic and genotypic features within the $C$. arcticum species complex may offer new options for transforming commercial, cultivated chrysanthemums.

We have characterized the genetic variation among extant, wild populations of $C$. arcticum and $C$. a. subsp. arcticum, based on 7,449 Single nucleotide polymorphism (SNP) markers from DArTseqLD [19, 20]. SNP data distinctly separated these two taxa, based on STRUCTURE 2.3.4, principal coordinate analysis (PCoA), discriminant analysis of principal components (DAPC), and unweighted pair group method with arithmetic mean (UPGMA) [19], thus providing unique SNP markers for these two species. Possible linkage of these SNP markers with phenotypic (qualitative, quantitative) traits is of great interest, particularly for species-specific traits and those of commercial interest, such as salt tolerance. The objective of this study is to establish phenotypic differences among wild $C$. arcticum and $C$. a. subsp. arcticum individuals when grown in a uniform environment. Traits could be linked with these SNPs [19, 20] for future research. Populations (individuals) were evaluated for native soil type composition as well as \% survival in cultivation. We used univariate and multivariate analysis to categorize species with representative populations (as identified with SNP data) based on the phenotypic traits [18, 21, 22]. Traits recorded included plant height, inflorescence length, number of leaves, internode length, leaf length, leaf width, petiole length, number of days to visible bud date, number of days to flowering, lamina length, inflorescence diameter, disc floret diameter, fresh weight, dry weight and $\Delta$ flower weight. Soil samples 
were also sampled at the collection sites for analyses of sodium $\mathrm{(Na)}$ content, along with other nutrient levels. The null hypothesis tested for each phenotypic trait was: $\mathrm{H}_{0}$ : There is no difference in phenotypic variation of each phenotypic trait within and among extant populations of $C$. arcticum and $C$. arcticum subsp. arcticum.

\section{Methods}

Study Sites. This study focused on extant $C$. arcticum collected by Dr. Neil Anderson (University of Minnesota) during 2017-2018 from the coastline of southwest Alaska mainland (59 $46^{\prime} \mathrm{N}$ to $61^{\circ} 6^{\prime} \mathrm{N}$, $-146^{\circ} 16^{\prime} \mathrm{W}$ to $-151^{\circ} 51^{\prime} \mathrm{W}$ ) and $C$. arcticum subsp. arcticum collected from the coastline of the westernmost Aleutian Island, Attu Island (52 $48^{\prime} \mathrm{N}$ to $52^{\circ} 50^{\prime} \mathrm{N}, 173^{\circ} 9^{\prime} \mathrm{E}$ to $173^{\circ} 18^{\prime} \mathrm{E}$ ) (cf. Fig. 2, [19]). There were four collection sites on the Alaska mainland for nine extant $C$. arcticum populations $(n=225$ individuals in total; Table 1 cf. Fig. 3, [19]): Anchor Point ( $n=1$ population), Kenai ( $n=3$ populations), Ninilchik ( $n=1$ population), and Old Valdez ( $\mathrm{n}=4$ populations) (cf. Fig. 3, [19]) and 21 collection sites on Attu island along the coastline for 21 extant $C$. a. subsp. arcticum populations, Attu- 1 to Attu-21 ( $\mathrm{n}=326$ individuals in total; Table $1 \mathrm{cf}$. Fig. 4, [19]). All C. arcticum populations were in full flower at the time of collection (July, 2018) whereas all C. a. subsp. arcticum populations were only vegetative at the time of collection (May-June, 2018). Attu Island is the western-most Aleutian Island of North America [46,47] and is generally classified as an Arctic [48] or Hypo Arctic zones [49]. The climate on Attu island is cool $\left(3.8^{\circ} \mathrm{C}\right.$ mean annual temperature) with $90 \%$ of the days having measurable precipitation (average rainfall=1,372mm/yr.) [50]. Clones (ramets) of each ortet growing in the wild were collected for this study and were identical to those used to generate SNPs $[19,20]$. Taxonomic identification occurred using dichotomous keys in the wild by Dr. Neil Anderson with flowering plants (C. arcticum) whilst only vegetative specimens of $C$. arcticum subsp. arcticum were collected in the wild. Thus, subsequent flowering and identification of $C$. arcticum subsp. arcticum occurred after collection with flowering specimens one month later in the greenhouse. Identifications were confirmed by curators of the Bell Museum Herbarium (MIN; University of Minnesota). One specimen of each population was deposited as a voucher specimen for future study with the following herbarium voucher specimen identifiers: MIN 2744013, MIN 2744011, MIN 2744010, MIN 2744007, MIN 2743973, MIN 2743974, MIN 2744006, MIN 2744003, MIN 2744000, MIN 2743997, MIN 2743994, MIN 2743990, MIN 2743987, MIN 2743985, MIN 2743983, MIN 2743981, MIN 2743979, MIN 2743978, MIN 2743977, MIN 2743977, and MIN 2743975.

Germplasm. Where necessary, collection permits were issued for the collection and research of $C$. arcticum germplasm and soil sampling (USFWS No. 74500-17-018). In 2018, 225 individuals of $C$. arcticum were collected from the nine populations and 326 individuals of $C$. a. subsp. arcticum were collected from the 21 populations (Table 1 cf. Fig. 4, [19]). These plants were collected as rhizomes (C. a. subsp. arcticum individuals were vegetative whereas all $C$. arcticum were flowering and the complete flower stems were brought to the lab). In addition, bagged in resealable plastic bags (1.75 mil, 1 Quart Get Reddi® Reclosable Food Service Bags, https://www.usplastic.com/catalog/item.aspx? itemid $=128308 \&$ catid $=)$ and put on ice in a portable cooler. Samples were placed in a refrigerator ( 3- 
$5^{\circ} \mathrm{C}$ ) until eventual transport to the lab at the University of Minnesota (within 2-3 weeks after collection). Rhizomes were subsequently transplanted and rooted in the mist house, with an intermittent mist system (10 minutes of frequency; reverse osmosis water). Since the $C$. arcticum individuals were harvested with the flowers, reproductive data (with the exception of the number of days to visible bud date and flowering) was collected from them prior to rooting. The flower stems were then removed and placed into floral preservative for seed ripening (for use in subsequent experiments). After rooting for 1-2 weeks, plants were moved to an environmentally controlled glass greenhouse with a $24.4 \pm 3.0 / 18.3 \pm 1.5^{\circ} \mathrm{C}$ day/night daily temperature regime and a $16 \mathrm{hr}$ photoperiod (0600-2200 HR; long days). During the winter months, supplemental lighting was applied with $400 \mathrm{w}$ high pressure sodium high intensity discharge (HPS-HID) lamps, at a minimum of $150 \mu \mathrm{mol} \mathrm{m}^{-2} \mathrm{~s}^{-1}$ at plant level. The computerized greenhouse was in the St. Paul campus Plant Growth Facilities (University of Minnesota, St. Paul, MN). Fertigation water was applied twice daily, between 0700-0800 HR and 1600-1700 HR, using a constant liquid feed (CLF) of $125 \mathrm{ppm} \mathrm{N}$ supplied from a water-soluble 20N-4.4P-16.6K fertilizer (Scotts, Marysville, $\mathrm{OH}$ ). Monthly rotational fungicide drenches were administered (cf. [19]).

Soil Sampling. Soil samples were collected from all mainland Alaska (Anchor Point-1, Kenai-1, Kenai-2, Ninilchik-1, Old Valdez-1, -2, -3, -4) populations for $C$. arcticum individuals and one $C$. arcticum subsp. arcticum sample was collected from Attu island, population 10 (weight limit restrictions limited sampling all of the 21 populations, due to the need to transport via boat on the Bering Sea). Soil samples from mainland Alaska and Attu Island were collected at the base of the first plant collected, with a $250 \mathrm{~g}$ sample collected as topsoil subtending the existing plant material. Samples were returned to the lab in resealable plastic bags (1.75 mil, 1 Quart Get Reddi® Reclosable Food Service Bags, https://www.usplastic.com/catalog/item.aspx?itemid=128308\&catid=) and kept at 3-5C until submitted for Spurway Greenhouse, Florist, \& Nursery Crops testing at the Department of Soil, Water and Climate's University of Minnesota Soil Testing Laboratory (http://soiltest.cfans.umn.edu/) to determine nutrient and other factors of the native soil for species and subspecies. Soil samples were evaluated for $\mathrm{NO}_{3}{ }^{-} \mathrm{N}$ (mg/ $\mathrm{kg}$ soil), $\mathrm{SO}_{4}^{-} \mathrm{S}$ ( $\mathrm{mg} / \mathrm{kg}$ soil), Bray P (mg/ $\mathrm{kg}$ soil), $\mathrm{NH}_{4} \mathrm{OAc}-\mathrm{K}$ ( $\mathrm{mg} / \mathrm{kg}$ soil), organic matter or LOI OM (\%), water $\mathrm{pH}, 1: 1$ electrical conductivity or $\mathrm{EC}(\mathrm{mmhos} / \mathrm{cm})$, saturated paste extract EC $(\mathrm{mmhos} / \mathrm{cm})$, hot water boron ( $\mathrm{mg} / \mathrm{kg}$ soil), DTPA-Fe (mg/kg soil), DTPA Mn (mg/kg soil), DTPA Zn (mg/kg soil), DTPA Cu (mg/kg soil), exchangeable $\mathrm{NH}_{4} \mathrm{OAc}-\mathrm{K}$ (mg/kg soil), $\mathrm{NH}_{4} \mathrm{OAc}-\mathrm{Ca}$ ( $\mathrm{mg} / \mathrm{kg}$ soil), $\mathrm{NH}_{4} \mathrm{OAc}-\mathrm{Mg}(\mathrm{mg} / \mathrm{kg}$ soil), and $\mathrm{NH}_{4} \mathrm{OAc}-\mathrm{Na}$ (mg/kg soil). The $\mathrm{NH}_{4} \mathrm{OAc}-\mathrm{Na}$ (mg/kg soil) determined salt concentrations rather than just EC values since ECs represent dissolved solutes, including $\mathrm{Na}$.

Measurement of Phenotypic Traits. The phenotypic (morphological) characteristics investigated were based on the Chrysanthemum Test Guidelines criteria set by the International Union for the Protection of New Varieties of Plants and Plant Identification Terminology [18,21,22]. To obtain comprehensive morphological traits datasets for $C$. arcticum populations, the same clones were grown in 2018 (from rooting onwards) through 2019 to create data sets. In 2018, only ramets of C. arcticum subsp. arcticum flowered (100\%) which limited the data collection of flower data for $C$. arcticum ( $0 \%$ flowering). Thus, the experiment was continued into 2019 (after 6 weeks or 1000 hrs of cold at 3-5C [14]) in the event that any 
of the $C$. arcticum clones would subsequently flower. In the event that these did not flower in 2019, most reproductive traits (with the exceptions of the number of days to visible bud date and flowering) were measured on the flowers collected originally on site (see above). In 2018, plant height (cm), inflorescence length $(\mathrm{cm})$, number of leaves on the primary stem, internode length $(\mathrm{cm})$, inflorescence diameter $(\mathrm{cm})$, disc floret diameter $(\mathrm{cm})$, petal length $(\mathrm{cm})$, flower fresh weight $(\mathrm{g})$, flower dry weight, water in fresh flower ( $\Delta$ flower weight $(\mathrm{g})=$ fresh flower weight - dry weight) were recorded. In 2019, we added leaf morphology, leaf length $(\mathrm{cm})$, lamina length $(\mathrm{cm})$, petiole length $(\mathrm{cm})$, leaf width $(\mathrm{cm})$, leaf margin, shape and color. Plant height was measured using a standard ruler $(30 \mathrm{~cm})$ placed vertically from the tallest point of the canopy of an inflorescence (if flowering) or from the tallest leaf (if nonflowering) to the soil line (base of the plant). Inflorescence length was measured from the bracts to the top of the plant [51]. The color of each leaf, flower ray floret (petals) and disc floret were determined using the Royal Horticultural Society [24] chart with the visual appearance under natural sunlight in the greenhouse. Leaf morphological data was recorded by removing a representative, fully matured leaf from each individual and taking a photo of each leaf sample which were subsequently measured in Image $\mathrm{J}$ software [52]. Leaf length $(\mathrm{cm})$ was measured from the lamina tip to the base of the leaf where the leaf stem (petiole) ended at the node on the primary stem. Petiole length was measured from the base of the petiole (at the primary stem) to the lamina base; lamina length $(\mathrm{cm})$ was obtained by subtracting leaf length from the petiole length; leaf width $(\mathrm{cm})$ was measured from the widest lamina lobes. The number of leaves on the primary stem of each individual were counted and mean internode length $(\mathrm{cm})$ was obtained by the following equation:

\section{Mean internode length $(\mathrm{cm})=$ plant height $/$ leaf number}

Leaf shapes were classified into five types: flabellate, hastate, pandurate, oblong or round [21]. Leaf margins were classified into four types: cleft, crenate, entire, lobed or tripartite.

All $C$. arcticum populations were flowering in the wild during the 2018 collecting trips, but most failed to flower as clones thereafter in the greenhouse (2018-9; Table 2) despite being under, presumably, the correct photoperiod of long days to induce flowering. For $C$. arcticum subsp. arcticum, visible bud and flowering dates were recorded. In 2018, the number of days to visible bud date (VBD) was counted from the day plants were rooted in the greenhouse whereas in 2019, it was the date they were taken from the cooler after a six-week cold treatment $\left(3-5^{\circ} \mathrm{C}\right.$; [14]), to the day when terminal flower bud was visible. The number of days to flowering was counted from the same start date each year to the day the flower expanded to the widest diameter and was at anthesis (pollen shed).

Flower morphological traits were observed and recorded mainly during the mature flowering period (2018 data set for C. arcticum and 2019 data set for $C$. a. subsp. arcticum). Inflorescence diameter was measured by standard ruler from the widest points of the flower. Disc floret diameter was measured from the widest point of the yellow floret disc. The petal length $(\mathrm{cm})$ was calculated by the formula:

\section{Petal Length $(\mathrm{cm})=($ inflorescence diameter - disc diameter $) / 2$}


The first flower on each individual was cut and weighed for fresh weight (g), placed in a high temperature oven $\left(76.67^{\circ} \mathrm{C}\right)$ (Hotpack, Philadelphia, PA) for 24 hours, and then weighed to obtain dry weights $(\mathrm{g})$. To calculate the $\Delta$ flower weight or water content, the following equation was used:

\section{$\Delta$ flower weight $(g)=$ fresh weight $(g)$ - dry weight $(g)$}

Data analysis. We conducted a series of statistical analyses to evaluate the morphological characteristics and establish phenotypic relationships between species and subspecies and among populations. We used multivariate approaches to quantify the variance for each trait as well as qualify visible attributes (color) of $C$. arcticum and $C$. a. subsp. arcticum. We also used univariate and multivariate regression approaches based on previous studies $[53,54]$ to analyze the morphological characteristics among the nine extant $C$. arcticum populations and 21 extant $C$. a. subsp. arcticum populations, respectively. Three taxonomic groupings were established for the statistical analyses: Group one: species, subspecies; Group two: $C$. arcticum; Group three: $C$. arcticum subsp. arcticum. In our study, statistical analyses were conducted to detect the variation among the three taxonomic groupings: Groups one, two and three respectively, by considering corresponding quantitative morphological variables for individuals in each group. For Group one, the group label was set as $C$. arcticum and $C$. a. subsp. arcticum; 16 quantitative morphological variables were applied using PCoA. For Group two, the group label was set at nine extant populations of $C$. arcticum; 16 quantitative morphological variables were analyzed with PCoA. For Group three, PCoA was used to detect the differences among the 21 populations of $C$. a. subsp. arcticum by analyzing 16 quantitative morphological variables. Collected quantitative morphological data were analyzed and performed using R studio (v.1.3.959) and the Statistical Package for the Social Sciences (SPSS) software, v.25.0 [55].

Two multivariate analyses, principal component analysis (PCOA) and Pearson's correlation were performed. The PCoA is one of the most effective and frequently used multivariate statistical methods for investigating a large set containing individuals/entities of multiple inter-correlated variables [56,57]. PCoA reduces the dimensionality of a multivariable dataset to few new variables, termed principal components, which correspond to a linear combination of the original variable [57]. Each principal component was reassigned a different portion of original variables, whereby PC1 would be considered as the greatest weight, PC2 would be the second, etc. [54]. Principal components analyses for three groups (Group one, two, three) were conducted with R studio by using the FactoMineR [56] and factoextra R packages [58]. The relatedness between morphological traits among populations for each group were assessed using Pearson's correlation coefficients and tested at $p \leq 0.05$ and $p \leq 0.01$ [59].

Univariate Analysis of Variance (ANOVA; general linear model) and descriptive statistics were conducted using SPSS to identify the discriminative descriptors and statistically differentiate among populations for quantitative phenotypic characteristics. Mean separations were conducted using $5 \%$ Tukey's Honestly Significant Difference (HSD) test at $\mathrm{a}=0.05$. The ANOVA analyses applied to $C$. arcticum and $C$. $a$. subsp. arcticum species, separately. While the $C$. arcticum dataset was combined by using both data from year 2018 and 2019, C. a. subsp. arcticum only included the data from 2019. The morphological variables 
from different years and different species would influence the univariate in the analyses. Hence, the comparison between species and subspecies would not be included in the univariate analysis of variance. The variation within and among populations of $C$. arcticum and $C$. a. subsp. arcticum between leaf quality morphological variables (leaf shape and leaf margin) was compared by a Chi-square ( $\chi 2)$ test for equal distribution across the five classes for the leaf shape and leaf margin data (1:1:1:1:1 $\chi 2)$.

\section{Results}

Pedological environment condition. The soil test results revealed considerable disparity between the recommended greenhouse soil standards and collection sites' samples (Table 1). The concentration of nitrate-nitrogen $\left(\mathrm{NO}_{3}-\mathrm{N}\right)$ from both the mainland Alaska and Attu island collection sites were significantly lower than the greenhouse standard, especially Attu island which had $<0.05 \mathrm{ppm} \mathrm{N}$. The electrical conductivity (EC) or relative dissolved soluble salt levels were in the range of 0-2 mmhos/cm (millimhos per centimeter) are non-saline, which occurred for soil samples from Ninilchik, Old Valdez-1, -2, -3, and -4 collection sites, the mainland Alaska, and the soil samples from Attu island. The Kenai-1 population had 2.1-4 mmhos/cm, or very slightly saline, whereas 4.1-8 mmhos/cm (moderately saline) was found for the soil samples from Anchor Point and Kenai-2 populations on mainland Alaska.

Additional soluble salt concentration and sodium $(\mathrm{Na})$ level tests provided additional data on salt tolerance. The saturated paste extract EC could only be run for four populations (Table 1) due to insufficient quantities for testing. The standard reference values and relative salt tolerance of crops ranges from 0 to 2, 3-4, 5-7 with a maximum of 8-10 mmhos $/ \mathrm{cm}$. Old Valdez-4 population had the lowest of $2.5 \mathrm{mmhos} / \mathrm{cm}$, followed by Kenai-1 at $4.8 \mathrm{mmhos} / \mathrm{cm}$, to Kenai-2 of $7.9 \mathrm{mmhos} / \mathrm{cm}$ and Anchor Point with the highest level of $14.7 \mathrm{mmhos} / \mathrm{cm}$ (Table 1). According to the soil testing laboratory, the soil sample from Old Valdez-4 would be considered slightly saline. The Kenai-1 population would be considered moderately saline whereas Kenai-2 and Anchor Point would be saline. Exchangeable $\mathrm{NH}_{4} \mathrm{OAc}-$ $\mathrm{Na}$ or sodium concentrations in all populations of both $C$. arcticum and $C$. a. subsp. arcticum collected were many levels of magnitude greater than the recommended greenhouse soil standard of $0-10 \mathrm{mg} / \mathrm{kg}$ (Table 1). For example, Attu Island (C. a. subsp. arcticum) had the lowest level of $123.94 \mathrm{mg} / \mathrm{kg}$, followed by increasingly higher concentrations of $\mathrm{Na}^{+}$in the $C$. arcticum populations, with the highest recorded in Anchor Point, AK at $2445.74 \mathrm{mg} / \mathrm{kg}$ (Table 1).

The water $\mathrm{pH}$ level of soil samples from the mainland Alaska sites ranged from 6.1 to 6.9 , within the normal range for greenhouse crops whereas Attu Island $\mathrm{pH}=4.8$ is considerably more acid (Table 1). The Bray-P test was used when the soil $\mathrm{pH}$ is $<7.4$ (otherwise, the Olsen-P test will be used). These soil samples collections, except for Anchor Point and Ninilchik, were within the standard range as greenhouse standard (5-15 mg/kg soil; Table 1). Anchor Point and Ninilchik collection sites had higher levels of phosphorus ( $\geq 15 \mathrm{mg} / \mathrm{kg}$; Table 1). The concentration of $\mathrm{NH}_{4} \mathrm{OAc}-\mathrm{K}(\mathrm{mg} / \mathrm{kg}$ soil) of soil samples from Anchor Point (280 mg/kg), Kenai-1 (278 mg/kg), and Kenai-2 (247 mg/kg; Table 1) collection sites were greater than the range of the Greenhouse standard $75-200 \mathrm{mg} / \mathrm{kg}$ soil, while the other samples fell within this range. Extractable Zinc, Copper, Iron, and Manganese concentrations, reported as DTPA-Zn, DTPA-Cu, 
DTPA-Fe, and DTPA-Mn ( $\mathrm{mg} / \mathrm{kg}$ soil) respectively, were frequently higher than the greenhouse standards (Table 1). Meanwhile, the exchangeable Potassium, Calcium, and Magnesium concentrations were reported as Exchangeable $\mathrm{NH}_{4} \mathrm{OAc}-\mathrm{K}, \mathrm{NH}_{4} \mathrm{OAc}-\mathrm{Ca}$, and $\mathrm{NH}_{4} \mathrm{OAc}-\mathrm{Mg}$, respectively, also indicated high variation among the samples with exchangeable $\mathrm{Ca}$ and $\mathrm{Mg}$ having the highest range of values.

\% Survival in Cultivated Conditions. Since the growing requirements for species and subspecies are completely unknown, we rooted the rhizomes and grew the clones in our standard greenhouse conditions (no added $\mathrm{Na}$ in the soilless medium) used for cultivated chrysanthemums (as described earlier) $[13,14,23]$. The $C$. arcticum populations survived sub optimally with all populations experiencing losses, ranging from $7.7 \%$ (Ninilchik) to $45.9 \%$ plant death (Old Valdez-1; Table 2). In contrast, all of the C. $a$. subsp. arcticum populations had $0 \%$ plant death (Table 2 ).

Morphological data. A total of 21 morphological characteristics for 225 C. arcticum individuals from nine populations and 326 C. a. subsp. arcticum individuals from 21 populations were found to be significantly different for the majority of characteristics measured (Table 3). Since the Attu-21 population contained $<3$ individuals $(n=1)$ it was automatically eliminated by the SPSS program for ANOVAs. Hence, a total of 29 populations were analyzed. Except for flower fresh, dry and $\Delta$ Flower weight variables, all species, populations and species* population interactions were very highly significant $(p \leq 0.001)$.

Mean plant height ranged from $21.3 \mathrm{~cm}$ (Attu-1; which overlapped with all other $C$. a. subsp. arcticum populations) to $47.1 \mathrm{~cm}$ (Ninilchik; Table 3 ) and there was very highly significant variation among $C$. arcticum and $C$. a. subsp. arcticum species $(F=11420.89, p \leq 0.001)$. The $C$. a. subsp. arcticum populations differed significantly from $C$. arcticum for mean plant height, except for all of the Old Valdez populations (Table 3). The Ninilchik population was significantly different from all other populations of $C$. arcticum as well as $C$. a. subsp. arcticum whereas the three Kenai populations overlapped with both Ninilchik and Anchor Point. Plant height cannot be considered a diagnostic trait for these species and subspecies.

Mean inflorescence lengths, ranging from $1.6 \mathrm{~cm}$ (Attu-2) to $21.4 \mathrm{~cm}$ (Old Valdez-2; Table 3) consistently showed highly significant variation among both species and subspecies $(F=2314.247, p \leq 0.001)$. The shortest mean inflorescence lengths were contained in all of the $C$. a. subsp. arcticum populations which did not overlap with any of the $C$. arcticum (Table 3 ). Thus, inflorescence length differs significantly between species and subspecies, and is a diagnostic trait. The Ninilchik population differed significantly from only the Old Valdez-1, -2 , and -3 populations but overlapped with the other $C$. arcticum populations. Whereas, there was no significant difference among $C$. $a$. subsp. arcticum populations for inflorescence length (Table 3).

The number of leaves on each primary inflorescence stem ranged from 9.8 (Old Valdez-2) in C. arcticum to 33.7 (Attu-7; Table 3) in C. a. subsp. arcticum. The nine $C$. arcticum populations differed from Attu- 1 to Attu-7 populations significantly $(p \leq 0.001)$. Interestingly, despite most of the $C$. arcticum subsp. arcticum populations having shorter plant height than $C$. arcticum, Attu- 1 through Attu-6 populations had 
significantly greater numbers of leaves on the primary stems (Table 3). The internode length ranged from $0.8 \mathrm{~cm}$ (Attu-7) to $4.0 \mathrm{~cm}$ (Old Valdez-1; Table 3) with a highly significant difference between $C$. arcticum and $C$. a. subsp. arcticum species ( $\mathrm{F}=3420.38, p \leq 0.001)$. The Attu- 1 to -7 and Attu- 12 and Attu-14 populations differed significantly from all $C$. arcticum populations on the internode length morphological trait. Thus, they are distinctly different for this trait. As a result, both leaf number and internode lengths are not diagnostic traits between species and subspecies.

Leaf lengths ranged from $5.7 \mathrm{~cm}$ (Old Valdez-3) to $18.3 \mathrm{~cm}$ (Attu-17; Table 3), while a significant difference was found between $C$. arcticum and $C$. a. subsp. arcticum species ( $F=5199.363, p \leq 0.001)$. The Attu-15 to -17 populations differed significantly from the $C$. arcticum populations (Table 3 ). Among the $C$. arcticum populations, Old Valdez-3 and Ninilchik differed from the rest significantly (Table 3 ). Mean leaf widths ranged from 2.1 (Old Valdez-3) to $7.1 \mathrm{~cm}$ (Attu-15; Table 3) with a significant difference between C. arcticum and $C$. a. subsp. arcticum species $(\mathrm{F}=6042.344, p \leq 0.001)$. C. arcticum populations differed significantly from all $C$. a. subsp. arcticum populations except for Attu-1 (Table 3). Among the $C$. $a$. subsp. arcticum populations, mean Attu-15 leaf width was significantly different from all other Attu populations, except for Attu-7, -16, -17 and -20. Mean petiole lengths, ranging from $3.3 \mathrm{~cm}$ (Old Valdez-3) to $12.4 \mathrm{~cm}$ (Attu-17; Table 3), varied significantly between the species and subspecies ( $F=3977.258$, $p \leq 0.001$ ). The Attu-15 and -17 populations differed significantly from all $C$. arcticum populations except for Ninilchik. Mean lamina lengths ranged from $2.4 \mathrm{~cm}$ (Old Valdez-3) to $6.0 \mathrm{~cm}$ (Attu-17; Table 3), showing highly significant variation between the species and subspecies ( $F=4485.451, p \leq 0.001)$. Attu-15 and -17 populations differed significantly from all $C$. arcticum populations except for the Ninilchik population. Overall, interestingly, the Attu-15 and -17 differed from the majority of $C$. arcticum populations except Ninilchik for leaf morphological traits. Due to the outlying populations within species, e.g. Ninilchik, Attu-17, and Old Valdez-3 which caused overlap among leaf morphological traits, none of these can be identified as diagnostic.

Leaf color [24] on the adaxial surface of $C$. arcticum population individuals was RHS 137 Green (Table 3) whereas that of $C$. a. subsp. arcticum populations were primarily the same color, although the Attu- 6 and Attu-16 populations were RHS 138 Green whilst Attu-18 and Attu-21 populations were RHS 139 Green (Table 3). Thus, most variation in adaxial leaf surface coloration occurred in C. a. subsp. arcticum; this trait is not diagnostic.

The majority leaf shapes for the nine $C$. arcticum populations were as flabellate, although a few individuals had hastate, oblong, pandurate and round (Table 3). The Ninilchik population did not have Hastate leaf shape although it was the second most commonly occurring leaf shape in $C$. arcticum (Table 3 ). The Anchor Point population was the only $C$. arcticum that had oblong leaf-shaped individuals (Table 3). The $C$. a. subsp. arcticum Attu-2 population had $100 \%$ flabellate leaf shape (Table 3 ). Unlike $C$. arcticum populations, $C$. a. subsp. arcticum did not have any oblong leaf-shaped individuals (Table 3 ). Hastate and pandurate leaf shapes were the most common among $C$. a. subsp. arcticum populations (Table 3). The 1:1:1:1:1 $\chi 2$ for leaf shape (flabellate : hastate : oblong : pandurate : round) did not differ significantly within populations (Table 3). Whereas, the pooled populations 1:1:1:1:1 $\chi 2$ for leaf shape 
was highly significantly different $(\chi 2=272.639, p \leq 0.001$; Table 3$)$ and did not fit an equal distribution. Thus, a specific leaf shape is not diagnostic of the species and subspecies.

A tripartite leaf margin was the most common type in all C. arcticum populations (Table 3 ). Except for the Attu-2 population, tripartite was also the most common leaf margin in all the other $C$. a. subsp. arcticum populations. The 1:1:1:1:1 $\chi 2$ for leaf margin types (cleft : crenate : entire : lobed : tripartite) did not differ significantly from expected, while a highly significant difference occurred among pooled populations $(X 2=283.693, p \leq 0.001)$. Since most populations, regardless of species, had one or two to five of the leaf margin types (cleft, crenate, entire, lobed, tripartite), this trait is not diagnostic.

Chrysanthemum arcticum and $C$. a. subsp. arcticum species were significantly different ( $F=15797.324$, $p \leq 0.001)$ for inflorescence diameter. This trait ranged from a mean of $4.3 \mathrm{~cm}$ (Old Valdez-1) to $5.8 \mathrm{~cm}$ (Attu-16; Table 3) and overlapped significantly within populations and among species. The Old Valdez-1 population was significantly different from the Attu-10, $-12,-16$ and -20 populations (Table 3 ). Disc floret diameter ranged from $1.2 \mathrm{~cm}$ (Attu-17) to $1.7 \mathrm{~cm}$ (Old Valdez-4, Attu-3; Table 3), with highly significant variation between species and subspecies $(\mathrm{F}=20431.789, p \leq 0.001)$. The $C$. a. subsp. arcticum Attu-17 population was significantly different from all $C$. arcticum populations except for Kenai- 1 and Kenai-2 (Table 3). Mean petal lengths were highly significantly different between $C$. arcticum and $C$. a. subsp. arcticum ( $\mathrm{F}=7606.809, p \leq 0.001)$, ranging from $1.4 \mathrm{~cm}$ (Old Valdez-1, Attu-1 and -2) to $3.2 \mathrm{~cm}$ (Attu-11; Table 3) among populations. The Attu-11 mean petal length was significantly longer from all other populations. None of these three floral traits (inflorescence diameter, disc floret diameter, and petal length) can be classified as diagnostic between the species and subspecies.

C. arcticum populations lack ray floret color and disc floret color data since it was not collected during or after plant collecting in 2018 and only seven plants flowered or reached VBD in 2019 (Table 2), although all ray petals observed in the field were white. Ray floret colorations of all $C$. arcticum subsp. arcticum populations were uniformly expressed as RHS 155 white (Table 3) while the disc floret colors ranged from RHS 14 yellow to RHS 15 and RHS 17 (Table 3).

None ( $0 \%)$ of the $C$. arcticum individuals flowered during the 2018 experimental year. However, a limited number of plants within some populations of $C$. arcticum subsequently flowered in late 2019, long after C. a. subsp. arcticum had completed flowering. Thus, only limited flowering data is available for this species since flowering stems collected in the wild needed to be used for all floral traits. Data missing from $C$. arcticum include the number of days to visible bud date (VBD) and to flowering (anthesis) for the majority of the populations of $C$. arcticum, since $96.9 \%$ (218/225 individuals) did not initiate flower buds and $97.8 \%(220 / 225)$ did not reach anthesis during 2018 or 2019 in the greenhouse test environment (Table 2). For the seven plants that did reach VBD and/or flower at the end of 2019, it took >1 year or 457 - $486 \mathrm{~d}$ (65.3 - $69.4 \mathrm{wks})$ among the seven individuals to reach VBD and 462 - $492 \mathrm{~d}$ (66 - $70.3 \mathrm{wks})$ to reach anthesis or flowering (Table 3), the longest period for either trait reported in chrysanthemum [13,14]. The seven individuals were from Anchor Point, Kenai-1, Kenai-3, and Old-Valdez-3 populations (Table 3). Thus, flowering data was collected in different years for both species and subspecies, due to the lengthy 
delays in $C$. arcticum flowering (Table 3 ). In contrast with the lengthy amount of time (>1 year) it took the seven $C$. arcticum individuals to flower, the mean number of days for $C$. arcticum subsp. arcticum individuals to reach VBD ranged from $48.33 \mathrm{~d}$ or $6.9 \mathrm{wks}$ (Attu-5 population) from the start of the experiment to $59.17 \mathrm{~d}$ or $8.45 \mathrm{wks}$ (Attu-3) under the same long day photoperiods. The $C$. arcticum subsp. arcticum mean number of days to flowering, also termed "response group" [14], ranged from $60 \mathrm{~d}$ or 8.57 wks (Attu-5) to $72.25 \mathrm{~d}$ or $10.3 \mathrm{wks}$ (Attu-16; Table 3). The mean duration of flower bud development from VBD to anthesis (flowering) in this species was extremely fast, taking as few as $11.67 \mathrm{~d}$ or $1.8 \mathrm{wks}$ (Attu5) to $21.55 \mathrm{~d}$ or $3.1 \mathrm{wks}$ (Attu-12) with a pooled mean across all populations of $15.73 \mathrm{~d}$ or $2.2 \mathrm{wks}$.

Due to lack of flowering in 2019, insufficient quantities of flowers occurred in several $C$. arcticum populations. Since fresh/dry weights could not be determined with the inflorescences collected in the wild in 2018 (due to seed ripening to obtain open-pollinated progeny), most of the flower weight data are missing (Table 3). Mean fresh weight of the flowers ranged from $0.59 \mathrm{~g}$ (Old Valdez-3) to $1.28 \mathrm{~g}$ (Attu-21; Table 3). In contrast, water loss created mean dry weights ranging from $0.06 \mathrm{~g}$ (Old Valdez-3) to $0.17 \mathrm{~g}$ (Attu-21; Table 3) / inflorescence. The $\Delta$ Flower weight (Fresh weight minus dry weight) values ranged from $0.53 \mathrm{~g}$ (Old Valdez-3) to $1.11 \mathrm{~g}$ (Attu-21; Table 3). None of these traits would be diagnostic for the species and subspecies.

Pairwise correlations among 16 quantitative variables were primarily positively and significantly correlated (Table 4). Plant height was significantly and positively correlated with inflorescence length $(r=0.610)$, the number of leaves $(r=0.311)$, disc diameter $(r=0.207)$, number of days to VBD $(r=0.366)$ and flowering ( $r=0.315)$, fresh $(r=0.157)$ and dry weights $(r=0.196$; Table 4). Plant height also had a highly significant negative correlation with internode length ( $r=-0.509)$, leaf length $(r=0 .-329)$, and leaf width $(r=-0.466$; Table 4). Inflorescence length was positively and significantly correlated with the number of days to VBD ( $r=0.644)$ and flowering $(r=0.678)$ but negatively and significantly correlated with internode length $(r=-0.718)$, number of leaves $(r=-0.604)$, leaf length $(r=-0.576)$, leaf width $(r=-0.651)$, petiole length $(r=-0.605)$, lamina length $(r=-0.380)$, and inflorescence diameter $(r=-0.199)$. Inflorescence length was positively correlated with flower dry weight $(r=0.034)$, while negatively correlated with flower fresh weight $(\mathrm{r}=-0.040)$ and $\Delta$ Flower weight $(\mathrm{r}=-0.051$; Table 4). Overall, plant height and inflorescence length were all negatively correlated with all four quantitative leaf morphological traits (Table 4). The number of leaves was significantly and positively correlated with internode length $(r=0.210)$, leaf length $(r=0.286)$, leaf width ( $r=0.326)$, petiole length ( $r=0.321)$, lamina length $(r=0.142)$ but negatively correlated with number of days to VBD ( $r=-0.180)$ and flowering $(r=-0.177$; Table 4$)$. Internode lengths were significantly and positively correlated with leaf length $(r=0.610)$, leaf width $(r=0.684)$, petiole length $(r=0.624)$, lamina length $(r=0.444)$, and flower petal length $(r=0.313)$ but negatively correlated with number of days to VBD $(r=-0.365)$ and flowering $(r=-0.295$; Table 4). Interestingly, the internode length was highly significantly and positively correlated with inflorescence diameter $(r=0.204)$ whereas it was negatively correlated with disc floret length $(r=-0.326)$.

Leaf length was highly correlated with leaf width $(r=0.839)$, petiole length $(r=0.972)$, lamina length $(r=0.837)$, but not as correlated with flower diameter $(r=0.247)$, flower petal length $(r=0.267)$, flower fresh 
weight $(r=0.052)$, and $\Delta$ Flower weight $(r=0.063 ;$ Table 4). Leaf length was negatively correlated with disc diameter ( $r=-0.221)$, number of days to VBD ( $r=-0.205)$ and flowering $(r=-0.153)$. Leaf width was positively correlated with petiole length ( $r=0.795)$, lamina length ( $r=0.749)$, inflorescence diameter $(r=0.212)$, and flower petal length $(r=0.237)$, while negatively correlated with disc diameter $(r=-0.221)$, number of days to VBD ( $r=-0.273)$, flowering $(r=-0.231)$. Leaf width was positively correlated with flower fresh weight $(r=0.051)$ and $\Delta$ Flower weight $(r=0.061)$, but negatively correlated with dry weight $(r=-0.026)$. Petiole length was positively correlated with lamina length $(r=0.684)$, inflorescence diameter $(r=0.240)$, while highly significant and negatively correlated with disc diameter $(r=-0.206)$, number of days to VBD $(r=-0.209)$ and flowering $(r=-0.163)$. Petiole length was positively correlated with flower fresh weight $(r=0.045)$, and $\Delta$ Flower weight $(r=0.057)$, but negatively correlated with dry weight $(r=0.030)$. Lamina length was highly significant and positively correlated with inflorescence diameter $(r=0.209)$, flower petal length $(r=0.229)$; was highly significant and negatively correlated with disc diameter $(r=-0.207)$. Lamina length was positively correlated with flower fresh weight $(r=0.050)$, and $\Delta$ Flower weight $(r=0.057)$, while negatively correlated with dry weight $(r=-0.001)$.

All four quantitative leaf morphological traits (leaf length, leaf width, petiole length and lamina length) were very significant and highly positively correlated with each other (Table 4) while all were negatively correlated to disc floret diameter, the number of days to VBD and flowering (except for lamina length), respectively (Table 4). Additionally, these four quantitative leaf morphological traits were all positively correlated with fresh weights and $\Delta$ Flower weight, while negatively correlated with dry weights, respectively.

The inflorescence diameter was positively and significantly correlated with all other floral traits (disc floret diameter, $r=0.273$; petal length, $r=0.838$; fresh weight, $r=0.229$; dry weights $r=0.159$; and $\Delta$ Flower weight, $r=0.238)$ ) while negatively but not significantly correlated with the number of days to flowering $(r=-0.003$; Table 4). The disc floret diameter was significantly and positively correlated with flower fresh $(r=0.208)$, dry weights $(r=0.231)$ and $\Delta$ Flower weight $(r=0.202)$; whereas, negatively correlated with flower petal length $(r=-0.022)$. Apparently, flower petal length was significantly positively correlated with inflorescence diameter $(r=0.838)$ and negatively correlated with disc floret diameter $(r=-0.022)$. The flower petal length was positively correlated with $\Delta$ Flower weight $(r=0.150)$ and fresh weights $(r=0.137)$, while negatively correlated with the number of days to VBD $(r=-0.010$, ) and flowering $(r=-0.028$; Table 4$)$. The number of days to VBD was positively correlated with the number of days to flowering $(r=0.989)$, and positively correlated with fresh $(r=0.086)$ and dry weights $(r=0.075)$ and $\Delta$ Flower weight $(r=0.086)$. The number of days to flowering was positively correlated with flower fresh weight $(r=0.104)$, dry weight $(r=0.082)$ and $\Delta$ Flower weight $(r=0.105)$. Fresh and dry weights and $\Delta$ Flower weight traits were significantly and positively correlated with each other, as would be expected.

Principal Components Analyses (PCoA). For Group one (both species and subspecies analyzed together), the first two principal components (PC1 and PC2) accounted for $50.1 \%$ of the variation (Fig. 18a). PC1 accounted for $31.3 \%$ of the total variation and was positively associated with number of leaves, leaf length, petiole length, lamina length and leaf width, ray floret diameter, flower petal length, flower fresh 
weight, dry weight and $\triangle$ Flower weight. PC1 was negatively associated with disc floret diameter, plant height, inflorescence length, internode length and the number of days to VBD and flowering (Fig. 18b). PC2 accounted for $18.8 \%$ of the total variation and was positively associated with most morphological variables, but negatively associated with leaf and petiole length and leaf width (Fig. 18b). The variable biplot revealed that fresh and dry weights and $\Delta$ Flower weight variables were closely clustered; leaf number, leaf length, petiole length, leaf width and lamina length were clustered together. All individuals were categorized as two groups into $C$. arcticum and $C$. a. subsp. arcticum species (Fig. 18c). In the scatter plot, two clusters showed overlapping distribution, yet separated distinctly along the PC1 for $30.1 \%$ of the total variance. Compared with $C$. arcticum, the $C$. a. subsp. arcticum group was dispersed widely along the PC2 for $18.8 \%$ of the total variance and presented more outliers from the ellipses.

For Group two, PCoA of 16 morphological variables of the nine populations of $C$. arcticum, 10 principal components were determined with $100 \%$ cumulative contribution (Fig. 19a). The first two principal components for Group two analysis, PC1 and PC2 accounted for $43.7 \%$ of total variation (Fig. 19b). PC1 accounted for $25.6 \%$ of total variance and was positively associated with leaf length, petiole length and lamina length, leaf width, plant height, flower diameter, flower petal length and all three flower weight characteristics. However, it was negatively associated with inflorescence length, flower disc diameter, internode length, and number of days to VBD and flowering. PC2 accounted for $18.1 \%$ of the total variance and was positively correlated with leaf width and length, petiole length and lamina length, internode length and inflorescence height, number of days to VBD and flowering. However, it was negatively correlated with inflorescence diameter, disc diameter, plant height, flower petal length, number of leaves, fresh and dry weights, and $\Delta$ Flower weight. Four quantitative morphological leaf variables were closely clustered together which were positively associated with PC1 negatively with PC2. Fresh, dry weights, and $\triangle$ Flower weights were clustered closely, associated with both PC1 and PC2 positively. However, instead of the relationship between species and subspecies, $C$. arcticum revealed a highly mixed distribution among the nine populations based on multivariate analysis of the morphological characteristics. According to the scatter plot (Fig. 19c), the Ninilchik population had a wider range of variation within population than other populations for $C$. arcticum species. Four individuals from the Ninilchik population were outliers from the overlapping distribution along with three individuals from Old Valdez-1, Old Valdez-3, and Old Valdez-4.

In contrast, Group three PCoA were relatively indistinguishable for the first two principal components (Fig. 20a), compared with Group one (Fig. 18a) and two (Fig. 19a) PCoAs. The first two principal components accounted for $43.6 \%$ of total variation derived from 16 quantitative morphological traits in the 21 populations of C. a. subsp. arcticum (Fig. 20a). PC1 accounted for $22.9 \%$ of total variance and was positively associated with all variables except for the number of leaves. PC2 accounted for $20.7 \%$ of total variance and was highly positively associated with fresh and dry weights, $\Delta$ Flower weight, number of days to VBD, flowering, the number of leaves, inflorescence and disc floret diameters, and flower petal length (Fig. 20b). It was negatively associated with leaf, petiole, lamina length and leaf width, plant height and inflorescence length (Fig. 20b). The fresh and dry weights and $\Delta$ Flower weight variables were closely clustered together, which were positively associated with both PC1 and PC2. The leaf length, leaf width, 
petiole and lamina lengths also clustered closely, which were positively associated with PC1 but negatively with PC2. Similar to the Group two analysis, the $C$. arcticum subsp. arcticum individual scatter plot showed a highly overlapping distribution among the 21 populations, based on the morphological characteristics. Individuals within populations tended to disperse along the PC1 instead of PC2.

\section{Discussion}

Soil test results overall showed lowered $\mathrm{N}$ levels across species and subspecies collection sites (Table 1), which may be consistent with heavy precipitation levels experienced in these sites, ranging from $7.26 \mathrm{~cm}$ to $16.84 \mathrm{~cm}$ in Attu island, while $6.76 \mathrm{~cm}$ to $22.89 \mathrm{~cm}$ at Old Valdez, $1.88 \mathrm{~cm}$ to $8.46 \mathrm{~cm}$ at Kenai, $2.54 \mathrm{~cm}$ to $7.57 \mathrm{~cm}$ at Anchor Point, and $2.39 \mathrm{~cm}$ to $8.66 \mathrm{~cm}$ at Ninilchik [25]. This doesn't mean that either species or subspecies are low $\mathrm{N}$ feeders; however, since no evidence of $\mathrm{N}$ toxicity occurred in either species or subspecies among all populations throughout this study despite being fed $125 \mathrm{ppm} \mathrm{N}$ as constant liquid feed (see Materials \& Methods) used for commercial chrysanthemums [14,26]. Thus, these Chrysanthemum species utilize available nitrate $\mathrm{N}\left(\mathrm{NO}_{3}^{-}\right)$during the growth phases.

Soil pH levels among both species and subspecies may be a physical diagnostic trait since all of the $C$. arcticum populations grow naturally in the standard soil $\mathrm{pH}$ range for the genus $(\mathrm{pH}=6.2-6.8$; Table 1$)$ $[14,26]$ C. a. subsp. arcticum populations grew in acidic soils at a $\mathrm{pH}=4.8$ (Table 1 ). The collection sites on Attu Island had high concentrations of sphagnum moss on the soil surface which favors lower $\mathrm{pH}$ levels, regardless of whether they were on cliff faces by the ocean or adjacent shoreline areas. Reasons for this site differences may be partially attributable to the high precipitation on Attu Island which allowed for predominance of sphagnum moss growth throughout the island wherein precipitation falls as either rain or snow every day of the year, although significant rain- and snowfall also occur in the mainland Alaskan sites. Despite the acid-tolerant trait for $C$. arcticum subsp. arcticum, no evidence of nutrient deficiencies occurred in any of the individuals during the 2018-2019 experimental period [26] when the soil $\mathrm{pH}$ was maintained within the $\mathrm{pH}=6.2-6.8$ range. Thus, the $\mathrm{pH}$ tolerance of $C$. arcticum subsp. arcticum has a wider range than that found in the Attu Island soil.

While most of the EC levels were within recommended ranges of low soluble salts (SS), both Anchor Point and Kenai-2 locations were in the saline range (Table 1). However, since these tests only measure SS, rather than $\mathrm{Na}$ levels in the soils, the $\mathrm{NH}_{4} \mathrm{OAc}-\mathrm{Na}$ amounts showed all soil sample sites to be excessively high in $\mathrm{Na}$, in contrast with the greenhouse recommended standard (Table 1) [26]. Even the lowest levels at Attu Island $(123.94 \mathrm{mg} / \mathrm{kg} \mathrm{Na}$ ) were high but surpassed by the increasingly higher amounts in the maritime sites on the Alaskan mainland where as much as $2445.74 \mathrm{mg} / \mathrm{kg}$ was found at Anchor Point, AK (Table 1). These incredibly high levels of $\mathrm{Na}$ in the soils adjacent to the ocean indicate a high level of salt tolerance in both species and subspecies which is unusual for any other chrysanthemum species $[13,14]$. This trait would be of significant interest to chrysanthemum breeding programs throughout the world, providing options for growing chrysanthemums in locations with saline water, in saline soils such as along roadways in northern latitudes where salt is used for ice melt in the winter months, as well as 
saline conditions in the desert southwest. Future studies will be devoted to analyzing the levels of salt tolerance in these species and subspecies as well as understanding the mechanism(s) involved.

While the levels of $P$ and $K$ were in the recommended range among the soil samples (Table 1 ), Anchor Point and Kenai- 1 and -2 collection sites were high in $\mathrm{K}$. Other nutrients, such as $\mathrm{Zn}, \mathrm{Cu}, \mathrm{Fe}, \mathrm{Mn}, \mathrm{Ca}$, and $\mathrm{Mg}$, were frequently higher than the norms (Table 1) [26] It was observed, particularly in the Attu Island sites, that significant WWII military waste may have seeped into the soils given the predominance of oil barrel dumps throughout the island where the 21 populations of $C$. a. subsp. arcticum were collected. Such tolerance to these micronutrients and heavy metals may indicate potential use of either species or subspecies in soil mitigation. Future studies will examine the levels of heavy metals in the leaves of Arctic daisy to determine whether they are sequestered therein.

High mortality rates of $7.7 \%$ to $45.9 \%$ among the $C$. arcticum populations is noteworthy, particularly since the $\mathrm{pH}$ range was kept within that found for the native soils (Table 2). These are in contrast with $0 \%$ mortality among all $C$. a. subsp. arcticum populations (Table 2). We observed that the dead individuals had root rot from unknown pathogens despite having routine applications of fungicide rotations applied. The specific reasons for this high mortality are unknown and deserve attention in future research.

Plant height of the Attu Island $C$. a. subsp. arcticum populations were all significantly shorter than most C. arcticum populations (Table 3), with the notable exception of all Old Valdez populations. It is unclear why the Old Valdez populations were significantly shorter than their counterparts from Ninilchik, Anchor Point or Kenai locations; it could be an evolutionary adaptive change since all populations are reproductively isolated due to highly mountainous terrain, although inbreeding depression could also be a possibility. Further research would be necessary to determine the reproductive barriers operating in both species and subspecies. Presumably, the species is self-incompatible, since most other Chrysanthemum species possess this reproductive barrier $[27,28]$. However, if either or both of these species and subspecies were diploid it is possible they are self-compatible, which could limit gene exchange within isolated populations and lead to reduced plant height [29]. Future research on self incompatibility is warranted.

Other morphological traits recorded did not prove to be distinguishing diagnostic characteristics between the species and subspecies, including leaf number of the primary stem, internode and leaf lengths, leaf width, petiole and laminar lengths, leaf color, leaf shape, leaf margins, inflorescence and disc floret diameters, ray and disc floret colors, and flower petal lengths (Table 3). Frequently, related leaf or floral traits were highly and significantly correlated with each other, as would be expected (Table 4). The number of leaves is similar in range to those reported for cultivated $C . \times$ grandiflorum and $C . \times$ hybridum [23]. Inflorescence length is a diagnostic trait, based on the significant differences among the species and subspecies with all individuals of $C$. $a$. subsp. arcticum having significantly shorter inflorescences than all C. arcticum (Table 3 ).

In this study we integrated conventional multivariate analysis techniques for 16 quantitative and five qualitative morphological characteristics for 525 individuals (Group one) to determine phenotypic 
differences between $C$. arcticum and $C$. a. subsp. arcticum and among populations within species and subspecies. The phenotypic data we collected were consistent with the historic record for $C$. arcticum and C. a. subsp. arcticum and were applied to identify the variation between the species and subspecies [1,8,30,31]. According to Nishikawa and Kobayashi [8], C. a. subsp. arcticum leaves tend to have a finely shallow sinus compared with $C$. arcticum species' deep and regularly toothed leaf margins. As expected, our collection (Table 3) matched the historic taxonomic records. Chrysanthemum a. subsp. arcticum populations tend to have more crenate leaf margins, while $C$. arcticum had more tripartite and lobed leaf margins (Table 3). The significant variation pooled among populations revealed by the Chi-square test for leaf margins indicated the diagnostic difference between $C$. arcticum and $C$. a. subsp. arcticum species (Table 3).

Consistently, it was found in the Group one PCoA that $C$. arcticum and $C$. a. subsp. arcticum were primarily separated as taxa (Fig. 18c). This distinguishable classification agrees with the genetic variation of SNP markers between $C$. arcticum and $C$. a. subsp. arcticum found previously $[19,20]$. The common morphological traits that $C$. arcticum and $C$. a. subsp. arcticum shared could be related to the overlapping distribution on the individual scatter plot for all individuals. However, this relatedness may be decreased due to the lack of gene flow between species, caused by the restrictive geographical separation $[19,20]$.

Since both species normally flower during the summer months (long day photoperiods) throughout the distributional range of Alaska (United States), Kamchatka (Russia), Hokkaido (Japan), and British Columbia, Hudson Bay (Canada), the species are considered to be long day plants for flower bud initiation (occurring prior to VBD) and flowering. All $C$. arcticum plants were at peak flowering in late July 2018 during collection trip, which means they would have initiated and developed flower buds during long day photoperiods. Our data with greenhouse forcing confirm this particularly well with $C$. a. subsp. arcticum (Table 3), $100 \%$ of which flowered in both years under long day conditions ( $16 \mathrm{hr}$ photoperiod). The significant lack of flowering within all populations of $C$. arcticum over a two-year period in the present study (2018-2019; Table 2) is curious. While a few individuals reached VBD (3.1\%; Table 2) and flowered (2.2\%) successfully, albeit after $~ 1.5$ years had passed under inductive long day photoperiods, clearly another factor(s) of plant growth is required for $C$. arcticum to reach VBD and flower successfully, as occurs in the wild. We postulate that Na levels in the soil or salt spray along the oceanic coasts may be a potential primary factor in the flowering process for this species. Future research will be devoted to this question to understand the factor(s), particularly $\mathrm{Na}$, and physiological mechanisms of this unusual phenomenon within $C$. arcticum. The long day flowering in the Chrysanthemum arcticum complex germplasm is the opposite of what is found in cultivated $C . \times$ grandiflorum and $C . \times$ hybridum $[14,23]$ which are short day plants ( $8 \mathrm{hr}$ photoperiod). However, $C$. arcticum and $C$. arcticum subsp. arcticum, as long day plants, would be similar to some other chrysanthemum species, such as pyrethrin, $C$. cinerariifolium [32].

Flower bud initiation (occurring prior to VBD) and development (flowering or anthesis) occurred extremely rapidly in all populations of $C$. arcticum subsp. arcticum (Table 3), i.e. 48.33 to $59.17 \mathrm{~d}$ (or 6.9 to 8.45 
wks) and 60 to $72.25 \mathrm{~d}$ (or 8.57 to 10.3 wks). At the time of collection, all terminal meristems of $C$. arcticum subsp. arcticum were examined under a dissecting microscope and determined to be in a vegetative state. The mean number of days to $\mathrm{VBD}=15.73 \mathrm{~d}$ or $2.2 \mathrm{wks}$ is the fastest ever reported within the genus [14], with some individuals initiating flower buds in the mist house while rooting. In contrast, the number of days to VBD and flowering in the seven individuals of $C$. arcticum took significantly longer periods of time, i.e. 457 to $486 \mathrm{~d}$ (or 65.3 to $69.4 \mathrm{wks}$ ) and 462 to $492 \mathrm{~d}$ (or 66 to $70.3 \mathrm{wks}$ ), respectively (Tables 1, 3).

By week 29 (2018), all of the $C$. arcticum plants in the wild were at peak flowering (Anderson N. O., unpublished data) and, based on field observations as well as greenhouse trials in the current experiment, neither species re-flowers in the same season. Thus, the observed flowering period was shorter than previously reported for either species or subspecies, e.g. flowering was noted in historic specimens to occur from May 21 (week 21) to September 25 (week 39) during the growing season across the geographical distributional range $[19,20]$. This shortened flowering period was assumed to be related to environmental factors, possibly global warming temperatures, that may have caused widespread extinction of the species, since they were reported as "common" in the historic records (as far back as 1865; N. Anderson, unpublished data) as well as taxonomic reports [33]. This trend agrees with the previous warming simulation studies [34], which showed major northward shifts and significant reductions of the tundra biomes in the Arctic, becoming restricted to coastal and mountainous areas [35]. From the perspective of conservation, future research will launch analogous analyses on our extensive collection of herbarium specimens on morphological traits for $C$. arcticum, C. a. subsp. arcticum and $C$. a. subsp. polaré and other related species, which will contribute to determine the extent and magnitude of a potential genetic bottleneck in the species occurring over time. Likewise, a morphological and genetic (SNP) study of $C$. a. subsp. polarépopulations in Alaska and Canada will be possible as soon as extant populations are collected to confirm whether or not this subspecies is similar to or divergent from both $C$. arcticum and C. a. subsp. arcticum.

Previous studies on chrysanthemum species and cultivar variation based on morphological characteristics, tended to focus on specific morphological traits with ornamental market value, such as inflorescence morphology and chemical composition [36-39] or descriptive traits for U.S. plant patents of plant breeder's rights $[22,23]$. The extensive morphological data sets, especially on qualitative and quantitative traits that best discriminate between species and populations of $C$. arcticum, $C$. a. subsp. arcticum and $C$. a. subsp. polaré is a valuable resource for future research. This morphological dataset will be enhanced with additional traits to facilitate the identification of phenotypes among species and populations and provide opportunities for marker assisted selection.

As noted earlier, the morphological variation among populations may not be distinguished significantly based on principal components analysis, although taxa differed significantly for specific traits. This may be associated with a close relatedness for individuals within and among populations. Meanwhile, the morphological variables we selected could fall into the common traits shared for species and subspecies or indistinguishable enough as diagnostic traits. However, the univariate analysis of variance provided a 
significant variation among populations consistent to our previous genetic variation studies. For example, for the $C$. arcticum extant populations, Old Valdez and Kenai populations tended to be significantly different from each other based on a majority of variables (Fig. 19): inflorescence length, number of leaves, internode length, inflorescence diameter, flower petal length. In contrast, Anchor Point and Ninilchik populations showed an intermediate tendency between Old Valdez and Kenai populations. The ANOVA among populations of $C$. arcticum showed a good consistency with our previous genetic structure analyses, suggesting that the variation between Old Valdez populations cluster and Kenai populations cluster contributed to the most significant variation among populations within the species. The variance among Anchor Point and Ninilchik populations contributed to the total variance secondarily (cf. PCoA analyses [19]).

The phenotypic variation noted in this study is in agreement with the genetic relatedness revealed in the UPGMA phylogenetic tree (based on using Jaccard genetic distance) $[19,20]$. A detailed genetic distance within each collection sites, such as for Old Valdez -1 and -2 populations in the same genetic ward whilst Old Valdez -3 and -4 populations were successively distant related $[19,20]$. The phenotypic variation obtained from this study in agreement with the genetic relatedness, Old Valdez populations, especially for Old Valdez -1 and - 2 groupings, very significantly different from other populations for the majority of morphological traits (Table 3). Additionally, the variance among populations based on morphological characteristics reconfirmed that the geographical isolation might be the major reason leading to the genetic and phenotypic variation among populations within $C$. arcticum.

In the ANOVAs, $C$. a. subsp. arcticum populations differed significantly from $C$. arcticum populations for the majority of morphological traits, although the range in variation within and among populations and species created overlap of many morphological traits (Table 3 ). This might be expected, since similarly indistinct clustering with the SNP cluster analysis for $C$. a. subsp. arcticum occurred, which verified the possibility of more frequency gene flow among Attu island collection sites $[19,20]$. The Attu populations' geographical distributions were not as distant as the $C$. arcticum populations were from each other. However, the UPGMA phylogenetic tree from SNPs revealed a detailed genetic distance among populations and presented a relatively close genetic relatedness in groupings $[19,20]$, which were consistent with some of the phenotypic relationships among populations (Table 3; Fig. 20). For example, the Attu-8 and Attu-9 populations differed from Attu- 1 to -7 populations significantly for internode length, leaf length, leaf width, which is in agreement with the Attu-8 and Attu-9 SNP populations groupings in the phylogenetic tree $[19,20]$. Interestingly, the Attu- $15,-16$ and -17 populations differed significantly from other populations for the majority of morphological traits whereas the genetic SNP analysis did not present significant variation between these groupings and other populations $[19,20]$. Testing these populations in additional environments would provide useful data on genotype $x$ environment interactions or the stability of trait expression.

Correlations showed that plant height was positively related to all the flower morphological variables except flower petal length (including inflorescence length, inflorescence diameter, disc floret diameter, flower weight), which confirmed a robust vegetative growing would benefit the reproductive growth (Table 
4). As expected, leaf morphology showed a significantly positive correlation among leaf variables, such as leaf, petiole, lamina lengths and leaf width for both $C$. arcticum and $C$. a. subsp. arcticum (Table 4). Floral morphological traits were also interrelated with significantly positive correlations among variables: inflorescence diameter, disc diameter, flower petal length, and a series of flower weight characteristics (Table 4). Other pairs of variables were inevitably correlated, such as inflorescence diameter and fresh weight (Table 4). As noted before, more morphological traits will be considered in the future research, such as pollen and seed morphological characteristics, presence of chemical compounds such as pyrethrin, ploidy and/or reproductive barrier(s) $[6,18,37]$. A thorough cytological study would be useful with this expansive germplasm collection within the $C$. arcticum species complex, since reported ploidy levels differ and differing levels may be diagnostic traits for the species and subspecies [40].

Besides the perspective of conservation, a better understanding of variation among species and populations will facilitate selection and use of advantageous traits. Since the production of chrysanthemum in the greenhouse often encounters high salinity, which is caused by the high irrigation frequency and high evapotranspiration [41], salt tolerance in chrysanthemum is becoming imperatively in the response to the growing demands of comprehensive chrysanthemum products worldwide, and the spreading application of automatic irrigation and environmental control systems [13,23,42,43]. At the same time, soil salinization is a growing problem worldwide. Salt accumulation in soils is mainly derived from snow melting agents, which would harm the garden mums. Chrysanthemum arcticum and its subspecies only grow in maritime habitats throughout Alaska and Canada as well as in acidic soils on Attu Island (Table 1), making it perfectly suited for developing salt-tolerant landscape perennials from these species and subspecies.

With the anticipated addition of $C$. arcticum subsp. polaré populations to the current germplasm bank, we will have a comprehensive genetic and morphological dataset. A series of studies will be aimed to combine the genetic (SNP marker) data and phenotypic datasets would be expected. Genome-wide association study (GWAS) would be an effective approach that can associate individuals with phenotypes effectively and simultaneously detect allelic variations and candidate genes from a preestablished set of germplasm [43-45]. Previous studies have detected on detecting SNPs associated with important horticultural traits via GWAS [43]. Sequencing the genomes, coupled with marker assisted selection will be valuable tools in furthering research on the species in the Chrysanthemum arcticum species complex.

\section{Conclusions}

Soil samples revealed extremely high levels of $\mathrm{Na}(\leq 2445 \mathrm{mg} . \mathrm{kg})$ tolerated by these maritime species which do not occur away from the oceanic coastlines; this salt tolerance is unique among Chrysanthemum species. A new diagnostic trait of inflorescence length was discovered to distinguish among $C$. arcticum and $C$. a. subsp. arcticum. Plant height in the uniform environment was also significantly different among the species with the exception of the $C$. arcticum Old Valdez populations. Both traits could be evolutionarily adaptable to the severe weather conditions in the Aleutian Island (Attu) 
where shorter inflorescence lengths may have adaptive significance [46]. Significant flowering differences occurred among the species wherein C. a. subsp. arcticum had $100 \%$ flowering for both years in a long day photoperiod (16 hr) whereas $C$. arcticum had $0 \%$ and $3.1 \%$ in years 1 and 2 , respectively. It is postulated that $\mathrm{Na}$ in soils or maritime salt spray may be induce flowering in $C$. arcticum. The mean number of weeks to visible bud date in $C$. a. subsp. arcticum is the fastest (2.2 wks.) ever reported for Chrysanthemum species, in contrast with $C$. arcticum which has the longest (65.3-69.4 wks.). This study on the species' variation in morphological and diagnostic traits is of importance to link morphological traits with single nucleotide polymorphism (SNP) markers. Genetic cluster analysis for $C$. a. subsp. arcticum verified the possibility of a higher frequency of gene flow among Attu island collection sites.

\section{Abbreviations}

ANOVA: analysis of variance; Ca: calcium; Cu: copper; DAPC: discriminant analysis of principal components; DArTseqLD: diversity arrays technology low density sequencing; EC: electrical conductivity; Fe: iron; GWAS: genome wide association mapping; $\mathrm{H}_{\mathrm{o}}$ : null hypothesis; HSD: Tukey's honestly significant difference test; $\mathrm{K}$ : potassium; Mg: magnesium; mmhos/cm: millimhos per centimeter; $\mathrm{Mn}$ : manganese; $\mathrm{N}$ : nitrogen; $\mathrm{Na}$ : sodium; $\mathrm{NH}_{4} \mathrm{OAc}-\mathrm{Na}$ : ammonium acetate; $\mathrm{NO}_{3}-\mathrm{N}$ : nitrate nitrogen; OAc-Na: sodium acetate; P: phosphorous; PC: principal component; PCoA: principal components analysis; SNP: single nucleotide polymorphism; SPSS: statistical package for the social sciences; SS: soluble salts; UPGMA: unweighted pair group method with arithmetic mean; VBD: visible bud date; $\chi 2$ : Chi-square; Zn: zinc.

\section{Declarations}

\section{Ethics approval and Consent to participate}

Not applicable.

\section{Consent for publication}

Not applicable.

\section{Availability of data and materials}

The datasets used and/or analyzed in the current study are available from the corresponding author on reasonable request.

\section{Competing interests}

The authors declare that they have no competing interests.

\section{Funding}


Funding for this research was provided, in part, by the Minnesota Agricultural Experiment Station and the N. Anderson Flower Breeding \& Genetics Foundation, to fund the 50\% Research Assistantship for Yunjia Liu's M.S. thesis and cover supply costs for this research.

\section{Authors' contributions}

NOA directed the entire research project. NOA, YL designed the research. YL performed the experimentation, YL and NOA analyzed the data. YL and NOA wrote the complete manuscript with equal contributions; NOA edited the manuscript. All authors read and approved the final draft of the manuscript.

\section{Acknowledgements}

Appreciation is extended to the following personnel who aided Neil Anderson in his 2017-2018 plant expeditions via boat throughout the Aleutian Islands (the Kodiak Archipelago: Kodiak Island, Long Island, Near Island, Pine Island; Adak Island; Kiska Island; Attu Island) and mainland Alaska (Anchor Point, Anchorage, Homer, Kenai, Ninilchik, Palmer, Seward, Valdez): Stacy Studebaker (botanist, Kodiak Island, AK); Dr. Suzie Golodoff (Aleutian Island taxonomist, Dutch Harbor and Unalaska, AK); Rachel Nummer and Cheryl Heyman (plant explorations, Kodiak Island, AK); Billy Choate (Captain), Alford Huff (substitute Captain), Zandra (cook) and Mike (engineer/deckhand) aboard the $22 \mathrm{~m} \mathrm{M/V} \mathrm{Pŭk-ŭk} \mathrm{boat} \mathrm{(Alaska} \mathrm{Marine}$ Expeditions, Homer, AK; http://www.pukuk.com/index.html); John Puschock and Neil Hayward (Zugenruhe Birding Tours, http://www.zbirdtours.com/); Pamela Russell (Div. of Parks and Outdoor Recreation, Alaska State Parks, Soldotna, AK; special parks use permit for collecting on Kodiak Island in Buskin River SWS, Ft. Abercrombie State Historical Park, Pasagshak SRA; Anchor River SRA; Ninilchik SRA; Deep Creek SRA; Clam Gulch SRA; Captain Cook SRA; Matanuska Glacier SRA; Squirrel Creek SRS; Tonsina SRS; Worthington Glacier SRS); Susan Alexander (Alaska Peninsula/Becharof National Wildlife Refuge, U.S. Fisheries and Wildlife Service; Special Use Permit \#17-302), Jeff Williams for the Aleutian Islands (U.S. Fisheries and Wildlife Service; Special Use Permit \#74500-17-018), Hansel Klausner and Lecita Monzon (Kodiak Island Refuge, U.S. Fisheries and Wildlife Service; Special Use Permit \#KOD.17.60006), and Todd Eskelin (Kenai National Wildlife Refuge, U.S. Fisheries and Wildlife Service). Special thanks are also extended to team members in the Anderson lab who helped with growing the plants, leaf collection, DNA extraction, and statistical analyses: Michele Schermann, Kaylie Niedzwiecki, Allison Graper, and Betty Ziskovsky.

\section{References}

1. Hultén E. Flora of Alaska and neighboring territories: a manual of the vascular plants. Stanford, CA: Stanford University Press;1968. Vol. 2193.

2. Steller GW, Frost OW. Journal of a voyage with Bering, 1741-1742. Stanford, CA: Stanford University Press; 1993.

3. Anderson NO. Reclassifications of the genus ChrysanthemumHortSci. 1987;22(2):313. 
4. Ohashi H, Yonekura K. New Combinations in Chrysanthemum (Compositae-Anthemideae) of Asia with a list of Japanese species. J Jap Bot. 2004;79:186-195.

5. Tzvelev N. Notae de speciebus nonnullis florae partis europaeae URSS. Novit Syst Plant Vaxs 1985;22:266-277.

6. Uehara A. Nakata M, Uchida A, Iwashina T. Chemotaxonomic consideration of flavonoids from the leaves of Chrysanthemum arcticum arcticum and yezoense, and related species. Biochem Syst Ecol. 2017;73:11-15.

7. Tolmatchew Al. Arctanthemum arcticum (Linnaeus) Tzvelev. Flora Arctica URSS. 1987;10:115 [cited in: Flora of North America 2019;9:536].

8. Nishikawa T, Kobayashi $\mathrm{H}$. Chromosome number and distribution of Chrysanthemum arcticum Jap Bot. 1989;64(3):77-84.

9. Budd AC. Budd's flora of the Canadian prairie provinces. Revised and Enlarged by Looman J, Best KF. Ottawa: Agriculture Canada; 1987.

10. Iwatsuki K, Yamazaki T, Boufford DE, Ohba H. In: Ōi J, Meyer FG, Walker EH. Flora of Japan. Washington DC: Smithsonian Institution; 1995. vol. 1.

11. Johnson KL. Wildflowers of Churchill and the Hudson Bay region. Winnipeg: Manitoba Museum of Man and Nature; 1987.

12. Studebaker S. Wildflowers and other plant life of the Kodiak Archipelago: a field guide for the flora of Kodiak and southcentral Alaska. Kodiak, AK: Sense of Place Press; 2010.

13. Anderson NO. (Ed.). Flower breeding and genetics: issues, challenges and opportunities for the $21 \mathrm{st}$ century. NY: Springer Science \& Business Media; 2006.

14. Dole JM, Wilkins HF. Floriculture: Principles and species. Upper Saddle River, NJ; Prentice Hall; 1999.

15. De Visser PHB, Van der Heijden GWAM, Marcelis LFM, Carvalho SMP, Heuvelink E. A functionalstructural model of chrysanthemum for prediction of ornamental quality. III International Symp on Models for Plant Growth, Env Control Farm Mgt in Protected Cultivation. 2006;718:59-66.

16. Zhang F, Jiang J, Chen S, Chen F, Fang W. Detection of quantitative trait loci for leaf traits in chrysanthemum. J Hort Sci Biotech. 2012;87(6):613-618.

17. Kim KY, Lee SS. Multivariate Analysis. Aurora, IL: Free Academy Press; 1995.

18. Kim SJ, Lee CH, Kim J, Kim KS. Phylogenetic analysis of Korean native Chrysanthemum species based on morphological characteristics. Sci Hort. 2014;175:278-289.

19. Liu Y. Genetic structure and phenotypic differences among and within extant populations of Chrysanthemum arcticum and C. a. subsp. arcticum. M.S. Thesis. Saint Paul, MN:Univ. Minnesota; 2020.

20. Liu Y, Anderson NO. Genetic structure (SNPs) of extant populations of Chrysanthemum arcticum and C. a. subsp. arcticum. Bot. 2020; submitted; under review.

21. Harris JG, Harris MW. Plant identification terminology: An illustrated glossary. Utah: Spring Lake Publishing; 1994. 
22. UPOV (the International Union for the Protection of New Varieties of Plants). Guidelines for the conduct of tests for distinctness, uniformity and stability (Chrysanthemum). UPOV, Geneva; 2008.

23. Anderson NO, Ascher P, Gesick E, Klossner L, Eash N, Fritz V, et al. Winter-hardy Mammoth ${ }^{\mathrm{Tm}}$ series $^{2}$ garden chrysanthemums 'Red Daisy', 'White Daisy', and 'Coral Daisy' sporting a shrub plant habit. HortSci. 2008;43(3):648-654.

24. Royal Hort Soc. RHS colour chart. London, The Society; J Roy Hort Soc. 1995;29(2).

25. Center WRC. Period of record monthly climate summary. Historical Climate Summaries for Puerto Rico and the US Virgin Islands. Chapel Hill: The Univ of North Carolina. 2014. https://sercc.com/climateinfo/historical/historical_pr.html Accessed 13 Feb 2019.

26. van Eysinga JR, Smilde KW. Nutritional disorders in chrysanthemums. Wageningen, The Netherlands; Instituut voor Bodemvruchtbaarheid, Pudoc; 1980.

27. Anderson NO, Liedl BE, Ascher PD, Widmer RE, Desborough SL. Evaluating self incompatibility in Chrysanthemum. Sexual Plant Reprod. 1988;1(3):173-181.

28. Zagorski JS, Ascher PD, Widmer RE. Multigenic self incompatibility in hexaploid Chrysanthemum. Euphytica 1983;32(1):1-7.

29. Anderson NO, Ascher PD, Widmer RE. Lethal equivalents and genetic load. Plant Breed Rev. 1992;10:93-127.

30. Bremer K, Humphries CJ. Generic monograph of the Asteraceae-Anthemideae. Bull Nat Hist Mus Botany Ser. 1993;23(2):71-177.

31. Porslid AE. Illustrated flora of the Canadian Arctic Archipelago; illustrated by Dagny Tande Lid. Bull Nat Mus Canada. 1957;146.

32. Brewer JG. Flowering and seed setting in pyrethrum (Chrysanthemum cinerariaefolium). A review. Pyrethrum Post. 1968;9(4):18-21.

33. Polunin NV. Botany of the Canadian Eastern Arctic: Part III: Vegetation and Ecology. Ottawa: Musée des beaux-arts du Canada; 1948.

34. Kaplan JO, New M. Arctic climate change with a 2॰ C global warming: Timing, climate patterns and vegetation change. Climatic Change. 2006;79(3-4):213-241.

35. Brown W.L. Genetic diversity and genetic vulnerability-an appraisal. Econ Bot. 1983;37(1):4-12.

36. Chen F, Jiang J, Guo WM. Heredity of several flower characters in Dendranthema grandiflora with small inflorescences. Acta Hort Sinica. 2003;30(2):175-182.

37. Hodaei M, Rahimmalek M, Arzani A. Variation in morphological characters, chemical composition, and anthocyanin content of different Chrysanthemum morifolium cultivars from Iran. Biochem Syst Ecol. 2017;74:1-10.

38. Song X, Gao K, Fan G, Zhao X, Liu Z, Dai S. Quantitative classification of the morphological traits of ray florets in large-flowered Chrysanthemum. HortSci. 2018a;53(9):1258-1265.

39. Song X, Zhao X, Fan G, Gao K, Dai S, Zhang M, ... et al. Genetic analysis of the corolla tube merged degree and the relative number of ray florets in chrysanthemum (Chrysanthemum $\times$ morifolium). Sci 
Hort. 2018b;242:214-224. Brouillet L. Arctanthemum. In: Tolematchew Al, editor. Flora Arctica URSS, Flora of North America; 1987. p. 535.

40. Liu QL, Zhong M, Li S, Pan YZ, Jiang BB, Jia Y, Zhang HQ. Overexpression of a chrysanthemum transcription factor gene, $D g W R K Y 3$, in tobacco enhances tolerance to salt stress. Plant Phys Biochem. 2013;69:27-33.

41. Chong $X$, Zhang $F$, Wu $Y$, Yang $X$, Zhao $N$, Wang $H, \ldots$ et al. A SNP-enabled assessment of genetic diversity, evolutionary relationships and the identification of candidate genes in chrysanthemum. Genome Biol Evol. 2016;8(12):3661-3671.

42. Tsirogiannis I, Katsoulas N, Kittas C. Effect of irrigation scheduling on gerbera flower yield and quality. HortSci. 2010;45(2):265-270.

43. Fang HL, Guo QS, Shen HJ, Li YC. Genetic diversity evaluation of Chrysanthemum indicum by medicinal compounds and molecular biology tools. Biochem Syst Ecol. 2012;41:26-34.

44. Li P, Zhang F, Chen S, Jiang J, Wang H, Su J, ... et al. Genetic diversity, population structure and association analysis in cut chrysanthemum (Chrysanthemum morifolium). Mol Genet Genomics 2016;291(3):1117-1125.

45. Sun Z, Wang X, Liu Z, Gu Q, Zhang Y, Li Z, ... et al. Genome-wide association study discovered genetic variation and candidate genes of fibre quality traits in Gossypium hirsutum Plant Biotech J. 2017;15(8):982-996.

46. Heusser CJ. Late Quaternary vegetation of the Aleutian Islands, southwestern Alaska. Can J Bot. 1990;68(6):1320-1326.

47. Talbot SS, Talbot SL. Numerical classification of the coastal vegetation of Attu Island, Aleutian Islands, Alaska. J Veg Sci. 1994;5(6):867-876.

48. Hultén E. Flora of the Aleutian Islands and westernmost Alaska Peninsula: With notes on the flora of Commander Islands. 2nd ed. New York: J. Cramer, Weinheim/Bergstr; 1960.

49. Yurtsev B.A. Floristic division of the Arctic. J Veg Sci. 1994;5(6):765-776.

50. Leslie LD. Alaska climate summaries. 2d ed. Anchorage, AK: Univ Alaska, Anchorage, Arctic Env Info Data Center, Alaska Climate Center Technical Note. 1989;5:118.

51. Chen Z, Huo Q, Yang H, Jian H, Qu C, Lu K, Li J. Joint RNA-Seq and miRNA profiling analyses to reveal molecular mechanisms in regulating thickness of pod canopy in Brassica napus. Genes. 2019;10(8):591.

52. Rueden CT, Schindelin J, Hiner MC, DeZonia BE, Walter AE, Arena ET, Eliceiri KW. ImageJ2: ImageJ for the next generation of scientific image data. BMC Bioinformatics 2017;18(1):529.

53. Lande R, Arnold SJ. The measurement of selection on correlated characters. Evol. 1983;37(6):12101226.

54. Murren CJ, Alt CH, Kohler C, Sancho G. Natural variation on whole-plant form in the wild is influenced by multivariate soil nutrient characteristics: natural selection acts on root traits. Am J Bot. 2020;107(2):319-328. 
55. Zar JH. Biostatistical analysis. Lebanon, IN: Prentice Hall; 1999.

56. IBM Corp. IBM SPSS Statistics for Windows. Armonk, NY: IBM Corp.; 2017. Ver. 25.0.

57. Lê S, Josse J, Husson F. FactoMineR: an R package for multivariate analysis. J Statistical Software 2008;25(1):1-18.

58. Kassambara A. Practical guide to principal component methods in R: PCoA, M (CA), FAMD, MFA, HCPC, factoextra; vol. 2. STHDA; 2017. http://www.sthda.com/english/ Accessed 10 May 2020.

59. Yang X, Ao N, Qu Y, Wu Y, Su J, Ding L, ... et al. Genetic characterization of anemone-type chrysanthemum (Chrysanthemum morifolium) using floral morphology and SRAP markers. Plant Breed. 2020;139(2):419-427.

60. Erwin JE. Soil test standards for potted plants and annuals. Minn Comm Flower Growers Bull. 1998;47(6):2.

\section{Tables}

Table 1. Soil test results (Spurway Greenhouse, Florist, \& Nursery Crops test, Soil Testing Laboratory, University of Minnesota) [60] from select Alaskan populations of $C$. arcticum (Anchor Point-1, Kenai-1, Kenai-2, Ninilchik-1, Old Valdez-1, -2, -3, -4) and C. a. subsp. arcticum (Attu Island) with greenhouse standard for crops, including chrysanthemum.

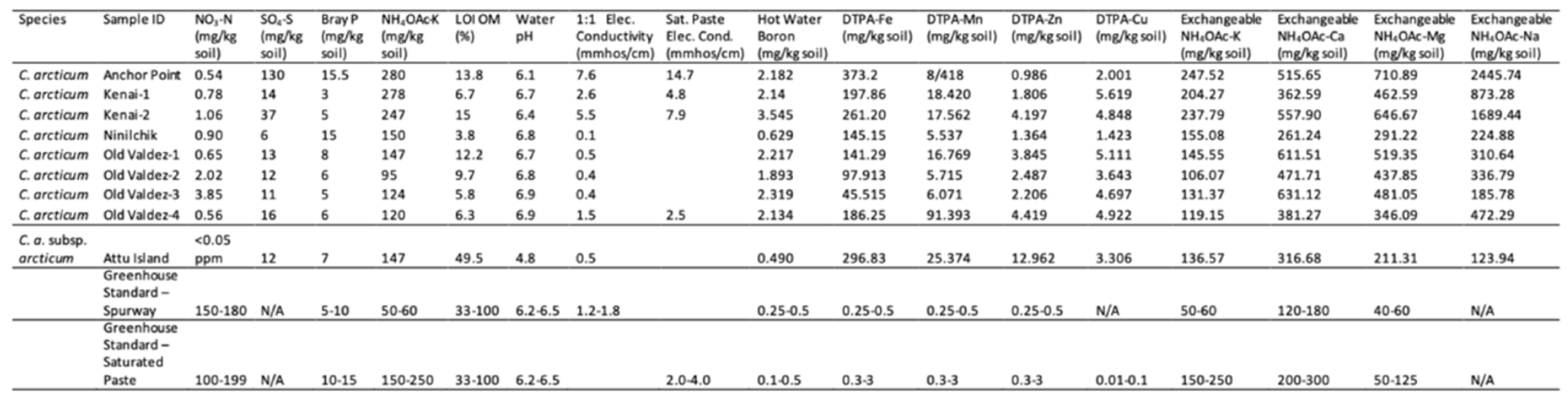

Table 2. Chrysanthemum. arcticum (nine populations) and C. a, subsp. arcticum data for clonal ramets (rhizomes rooted from the individuals collected in the wild) grown in the greenhouse during the 20182019 experimental period: plant death (number, \%), number of plants flowering (\%), range (mean) number of days to visible bud date (VBD) and range (mean) number of days to flowering. 


\begin{tabular}{llll}
\hline C. arcticum & Old Valdez-1 & $17 / 37(45.9 \%)$ & $0(0 \%)$ \\
& Old Valdez-2 & $5 / 18(27.8 \%)$ & $0(0 \%)$ \\
& Old Valdez-3 & $8 / 23(34.8 \%)$ & $1 / 23(4.3 \%)$ \\
& Old Valdez-4 & $5 / 15(33.3 \%)$ & $0(0 \%)$ \\
& Anchor Point & $11 / 40(27.5 \%)$ & $3 / 40(7.5 \%)$ \\
& Ninilchik & $1 / 13(7.7 \%)$ & $0(0 \%)$ \\
& Kenai-1 & $11 / 32(34.4 \%)$ & $2 / 32(6.2 \%)$ \\
& Kenai-2 & $7 / 22(31.8 \%)$ & $0(0 \%)$ \\
& Kenai-3 & $11 / 25(44.0 \%)$ & $1 / 25(4.0 \%)$ \\
C. a. subsp. arcticum & Attu & $0 / 326(0 \%)$ & $321 / 326(98.5 \%)$ \\
\hline
\end{tabular}

Table 3. Chapter 3 Mean values of $C$. arcticum (nine populations) and $C$. a. subsp. arcticum (21 populations) for 21 plant morphological traits (2018 data: C. arcticum plant height, inflorescence length, number of leaves, internode length, inflorescence diameter, disc floret diameter, flower petal length, flower fresh weight, flower dry weight and $\Delta$ flower weight; 2019 data: $C$. arcticum leaf length, leaf width, petiole length, lamina length and three qualitative traits (adaxial leaf color, leaf shape, leaf margin), number of days to visible bud date, number of days to flowering and $C$. a. subsp. arcticum all 21 morphological traits). Mean separations within traits (columns), are based on Tukey's 5\% HSD. Chi-square tests of two qualitative phenotypic traits (leaf shape, leaf margin) tested with equal probability of occurrence $(1: 1: 1: 1: 1 \times 2)$. One asterisk $(*)$ indicate a significant variation $(p<0.05)$; two asterisks $(* \star)$ indicate a highly significant variation $(p<0.01)$.

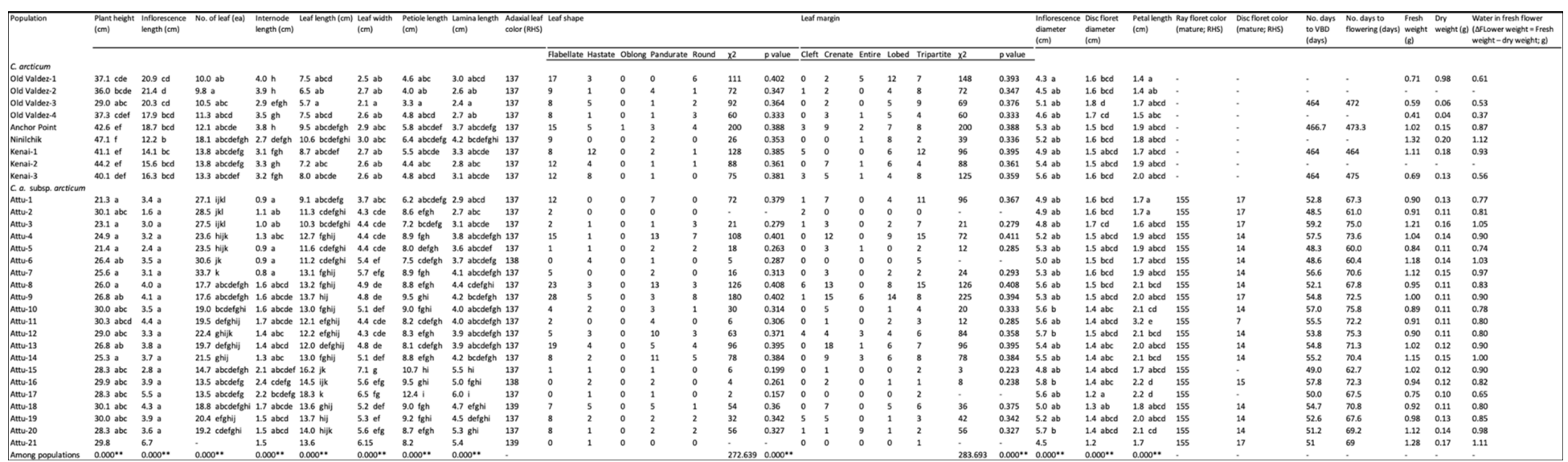

Table 4. Correlations between 16 quantitative plant morphological traits for $C$. arcticum (225 individuals) and $C$. arcticum subsp. arcticum (326 individuals) (2018 data: $C$. arcticum plant height, inflorescence length, number of leaves, internode length, inflorescence diameter, disc floret diameter, flower petal length, flower fresh weight, flower dry weight and $\Delta$ flower weight; 2019 data: $C$. arcticum leaf length, leaf width, petiole length, lamina length, number of days to visible bud date, number of days to flowering; and $C$. $a$. 
subsp. arcticum all 16 quantitative morphological traits). An asterisk (*) indicates a significant correlation coefficient $(P \leq 0.05)$, two asterisks $(* \star)$ indicate a highly significant correlation coefficient $(P \leq 0.01)$ whereas a lack of any asterisk(s) denotes not significant.

\begin{tabular}{|c|c|c|c|c|c|c|c|c|c|c|c|c|c|c|c|c|}
\hline & $\begin{array}{l}\text { Plant height } \\
(\mathrm{cm})\end{array}$ & $\begin{array}{l}\text { Inflorescence } \\
\text { length }(\mathrm{cm})\end{array}$ & $\begin{array}{l}\text { No. of } \\
\text { leaf (ea) }\end{array}$ & $\begin{array}{l}\text { Internode } \\
\text { length }(\mathrm{cm})\end{array}$ & $\begin{array}{l}\text { Leaf length } \\
(\mathrm{cm})\end{array}$ & $\begin{array}{l}\text { Leaf width } \\
(\mathrm{cm})\end{array}$ & $\begin{array}{l}\text { Petiole } \\
\text { length }(\mathrm{cm})\end{array}$ & $\begin{array}{l}\text { Lamina } \\
\text { length }(\mathrm{cm})\end{array}$ & $\begin{array}{l}\text { Inflorescence } \\
\text { diameter }(\mathrm{cm})\end{array}$ & $\begin{array}{l}\text { Disc floret } \\
\text { diameter }(\mathrm{cm})\end{array}$ & $\begin{array}{l}\text { Flower petal } \\
\text { length }(\mathrm{cm})\end{array}$ & $\begin{array}{l}\text { No. days } \\
\text { to VBD }\end{array}$ & $\begin{array}{l}\text { No. days to } \\
\text { flowering }\end{array}$ & $\begin{array}{l}\text { Fresh } \\
\text { weight (g) }\end{array}$ & $\begin{array}{l}\text { Dry weight } \\
\text { (g) }\end{array}$ & $\begin{array}{l}\Delta \text { Flower } \\
\text { weight (g) }\end{array}$ \\
\hline Plant height $(\mathrm{cm})$ & 1 & & & & & & & & & & & & & & & \\
\hline Inflorescence length $(\mathrm{cm})$ & $0.610^{* *}$ & 1 & & & & & & & & & & & & & & \\
\hline No. of leaf (ea) & $-0.311^{* *}$ & $-0.604^{* *}$ & 1 & & & & & & & & & & & & & \\
\hline Internode length $(\mathrm{cm})$ & $0.647^{* *}$ & $0.800^{* *}$ & $0.210^{* *}$ & 1 & & & & & & & & & & & & \\
\hline Leaf length $(\mathrm{cm})$ & $-0.329 * *$ & $-0.576^{* *}$ & $0.286^{* *}$ & $0.610^{* *}$ & 1 & & & & & & & & & & & \\
\hline Leaf width $(\mathrm{cm})$ & $-0.466^{* *}$ & $-0.651^{* *}$ & $0.326^{* *}$ & $0.684^{* *}$ & $0.839 * *$ & 1 & & & & & & & & & & \\
\hline Petiole length $(\mathrm{cm})$ & $-0.367^{* *}$ & $-0.605^{* *}$ & $0.321^{* *}$ & $0.624^{* *}$ & $0.972^{* *}$ & $0.795 * *$ & 1 & & & & & & & & & \\
\hline Lamina length $(\mathrm{cm})$ & $-0.169 * *$ & $-0.380^{* *}$ & $0.142^{* *}$ & $0.444^{* *}$ & $0.837^{* *}$ & $0.749 * *$ & $0.684^{* *}$ & 1 & & & & & & & & \\
\hline Inflorescence diameter $(\mathrm{cm})$ & 0.027 & $-0.199 * *$ & $0.226^{* *}$ & $0.204 * *$ & $0.247^{* *}$ & $0.212^{* *}$ & $0.240^{* *}$ & $0.209 * *$ & 1 & & & & & & & \\
\hline Disc floret diameter $(\mathrm{cm})$ & $0.207^{* *}$ & $0.333^{* *}$ & -0.013 & $-0.326^{* *}$ & $-0.221 *$ & $-0.238^{* *}$ & $-0.206 * *$ & $-0.207^{* *}$ & $0.273^{* *}$ & 1 & & & & & & \\
\hline Flower petal length $(\mathrm{cm})$ & -0.019 & $-0.273^{* *}$ & $0.198^{* *}$ & $0.313^{* *}$ & $0.267^{* *}$ & $0.237^{* *}$ & $0.258^{* *}$ & $0.229 * *$ & $0.838 * *$ & -0.022 & 1 & & & & & \\
\hline No. days to VBD & $0.366^{* *}$ & $0.644 * *$ & $-0.180^{* *}$ & $-0.365^{* *}$ & $-0.205 * *$ & $-0.273 * *$ & $-0.209 * *$ & $-0.135^{*}$ & 0.018 & 0.083 & -0.010 & 1 & & & & \\
\hline No. days to flowering & $0.315^{* *}$ & $0.678 * *$ & $-0.177^{* *}$ & $-0.295^{* *}$ & $-0.153 * *$ & $-0.231 * *$ & $-0.163 * *$ & -0.087 & -0.003 & 0.096 & -0.028 & $0.989 * *$ & 1 & & & \\
\hline Fresh weight (g) & $0.157^{* *}$ & -0.040 & 0.096 & 0.048 & 0.052 & 0.051 & 0.045 & 0.050 & $0.229 * *$ & $0.208^{* *}$ & $0.137^{*}$ & 0.086 & 0.104 & 1 & & \\
\hline Dry weight (g) & $0.196^{* *}$ & 0.034 & $0.130^{*}$ & -0.105 & -0.023 & -0.026 & -0.030 & -0.001 & $0.159 * *$ & $0.231^{* *}$ & 0.047 & 0.075 & 0.082 & $0.904^{* *}$ & 1 & \\
\hline$\Delta$ Flower weight (g) & $0.148^{*}$ & -0.051 & 0.089 & 0.071 & 0.063 & 0.061 & 0.057 & 0.057 & $0.238 * *$ & $0.202 * *$ & $0.150 * *$ & 0.086 & 0.105 & $0.997 * *$ & $0.873 * *$ & 1 \\
\hline
\end{tabular}

\section{Figures}
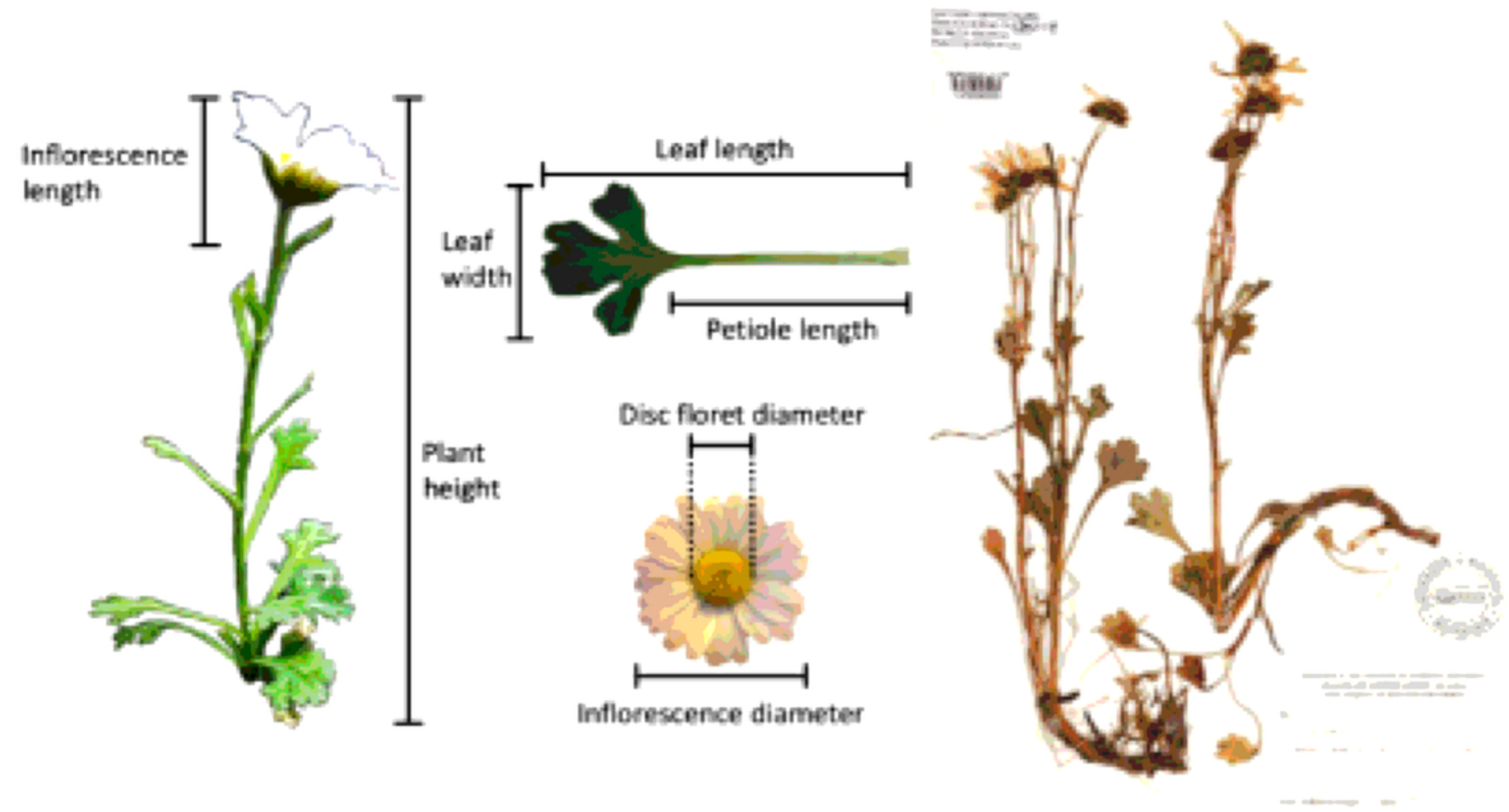

Figure 1

Chapter 3 Basic survey standard (left) of an extant specimen versus an historic or herbarium specimen (right) of C. arcticum species (Old Valdez-1). 


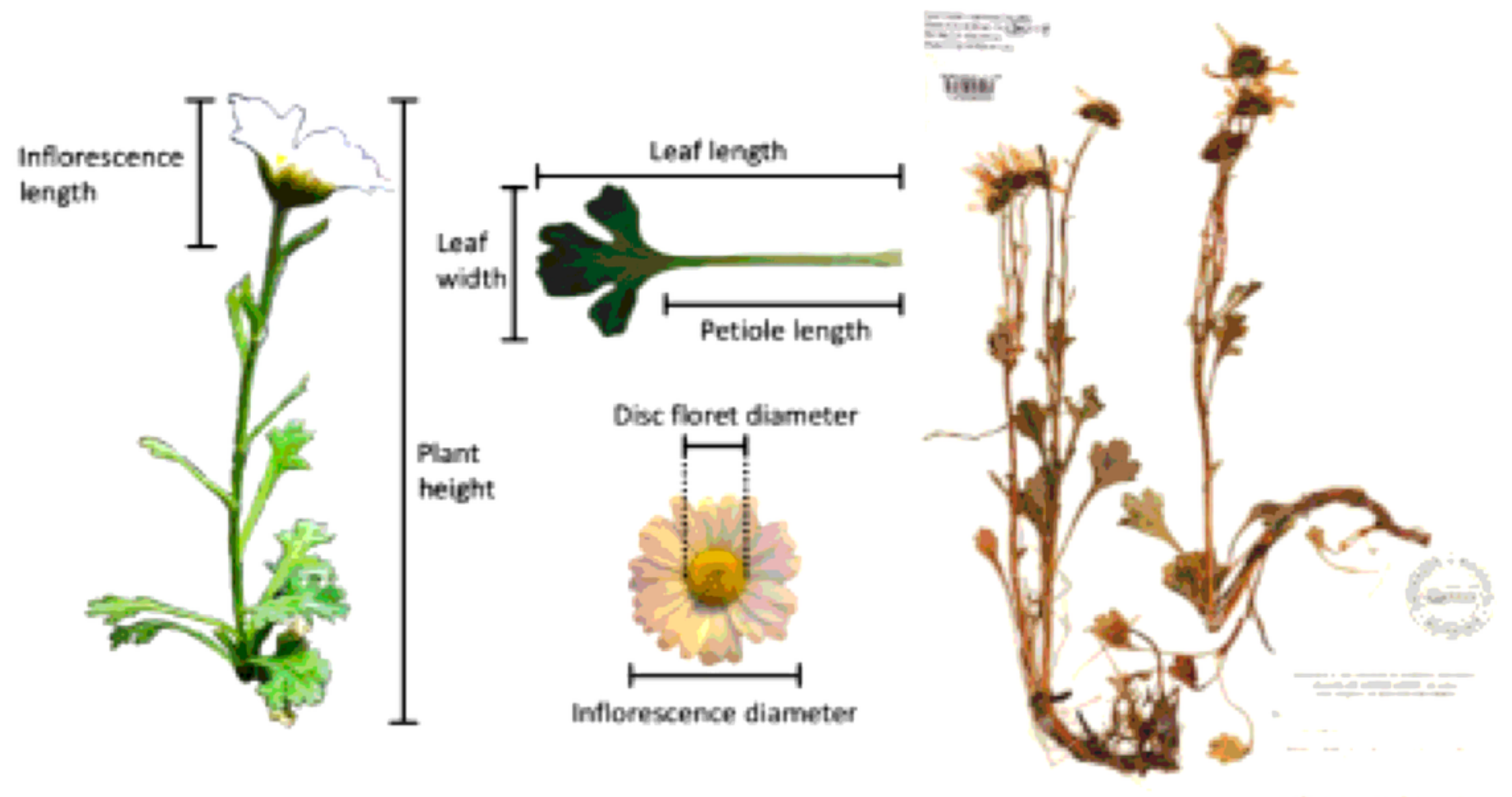

Figure 1

Chapter 3 Basic survey standard (left) of an extant specimen versus an historic or herbarium specimen (right) of C. arcticum species (Old Valdez-1).

(a)

(a) Scree plot

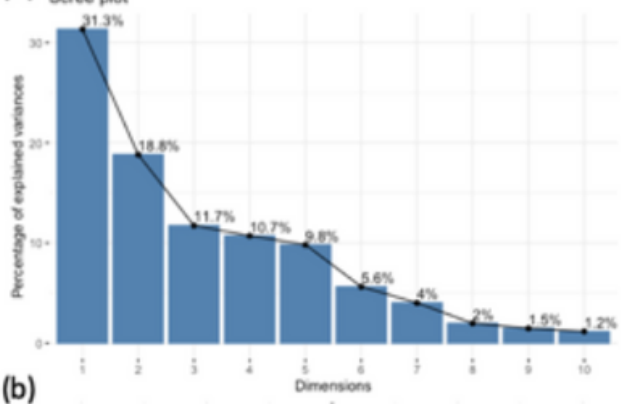

(b)

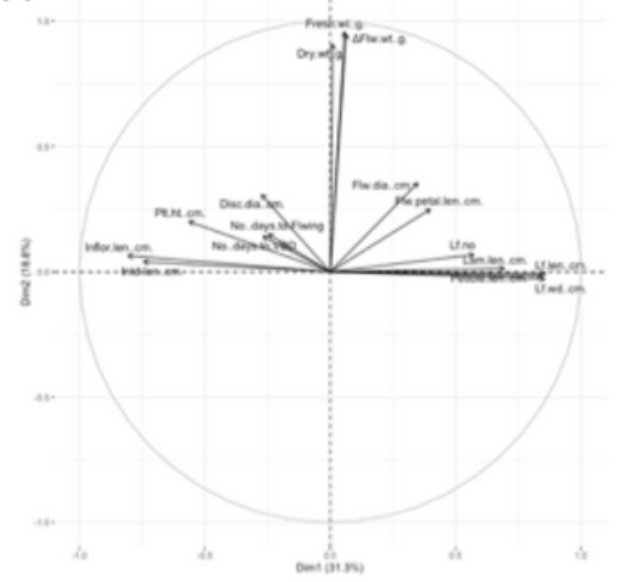

(c) Individuals - PCA

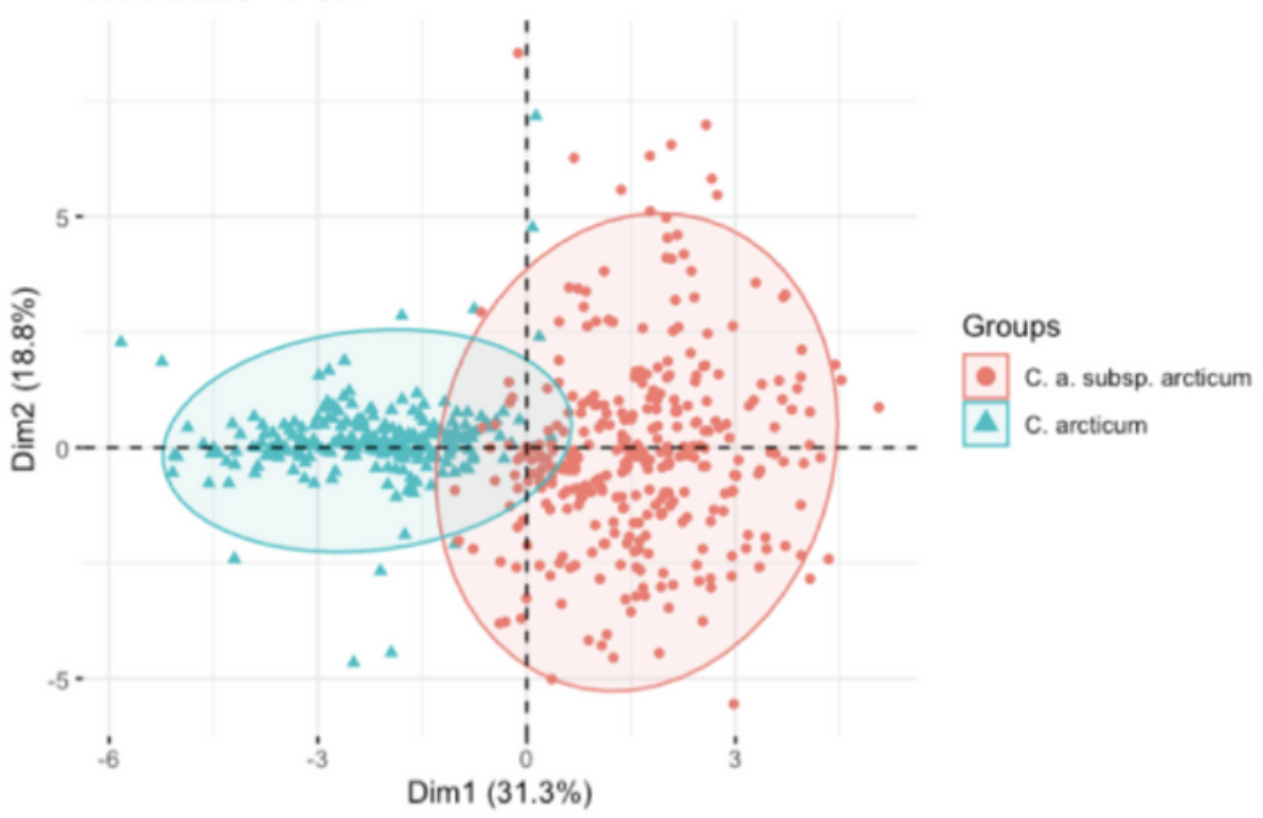




\section{Figure 2}

Chapter 3 Principal components analysis (PCoA) for C. arcticum and C. a. subsp. arcticum for 16 quantitative morphological traits. (a) Scree plot of principal component analysis of C. arcticum populations between eigen value and principal components; (b) variables plot revealed by two principal components analysis; (c) Individual scatter plot grouping by species with two principal components analyses.

(a)
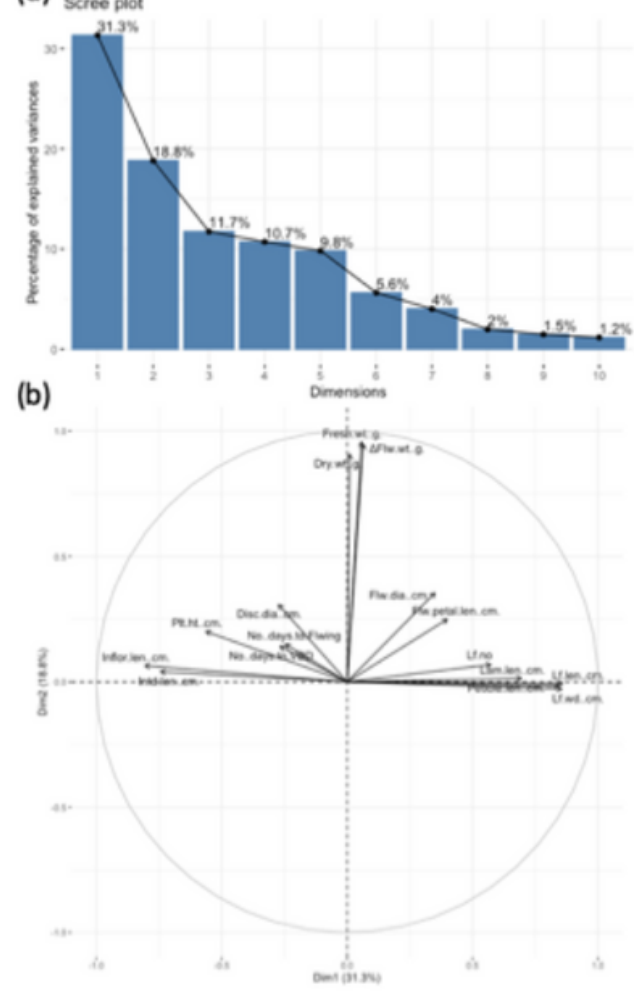

(c)

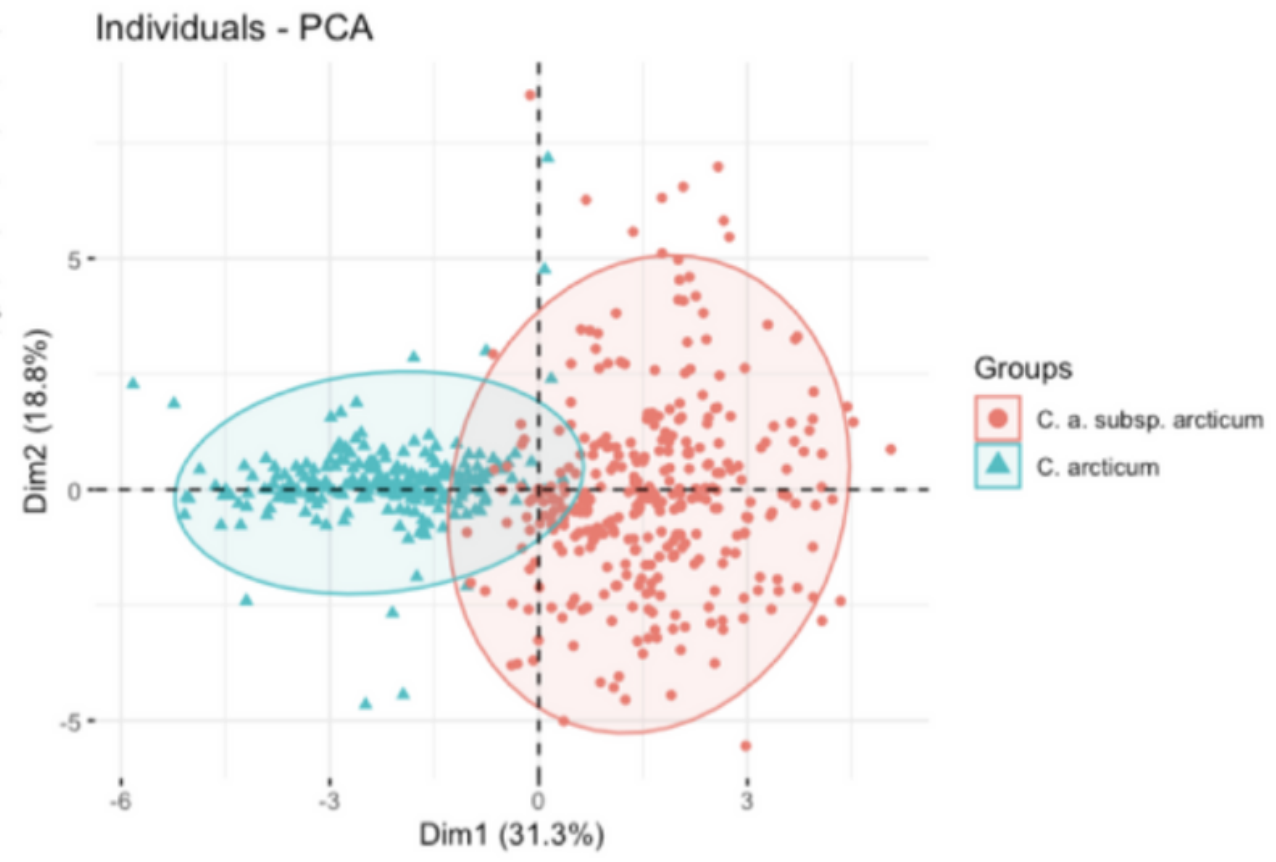

Figure 2

Chapter 3 Principal components analysis (PCoA) for C. arcticum and C. a. subsp. arcticum for 16 quantitative morphological traits. (a) Scree plot of principal component analysis of C. arcticum populations between eigen value and principal components; (b) variables plot revealed by two principal components analysis; (c) Individual scatter plot grouping by species with two principal components analyses. 
(a)

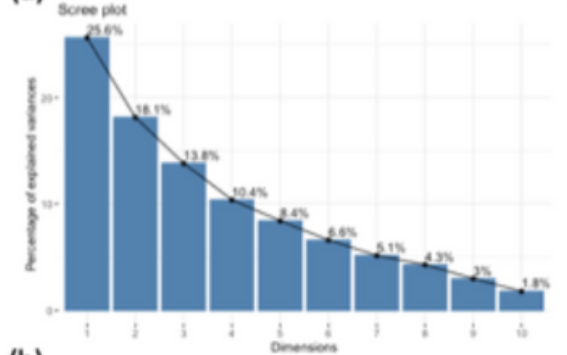

(b)

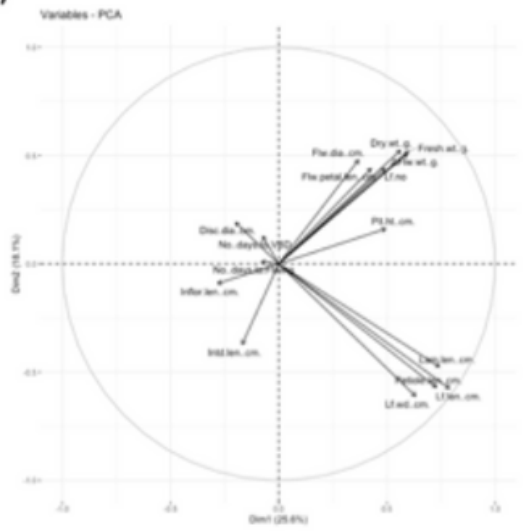

(c)

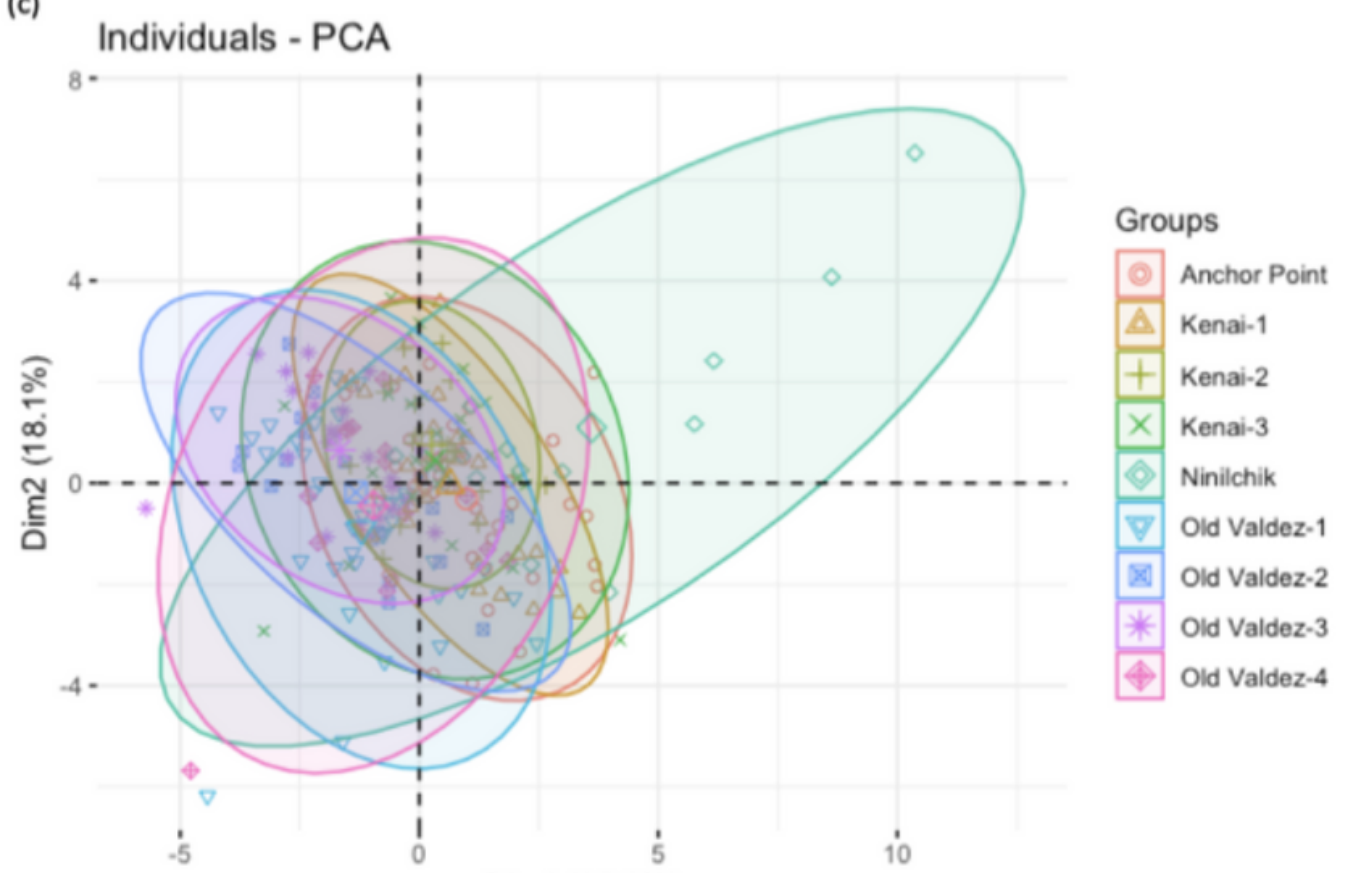

Dim1 (25.6\%)

\section{Figure 3}

Chapter 3 Principal components analyses (PCoA) for C. arcticum 16 quantitative morphological traits. (a) Variables plot revealed by two principal components analysis. (b) Scree plot of principal component analysis of $\mathrm{C}$. arcticum populations between eigen value and principal components. (c) Individual scatter plot grouping by populations revealed by two principal components analysis.

(a)

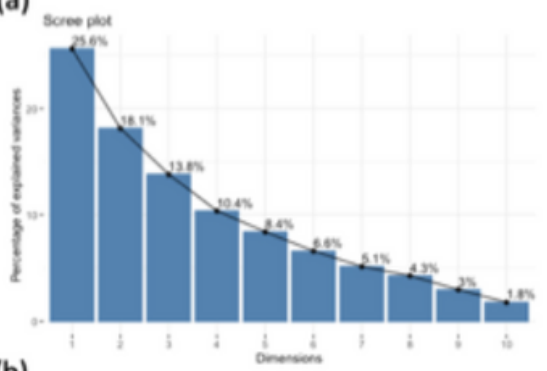

(b)

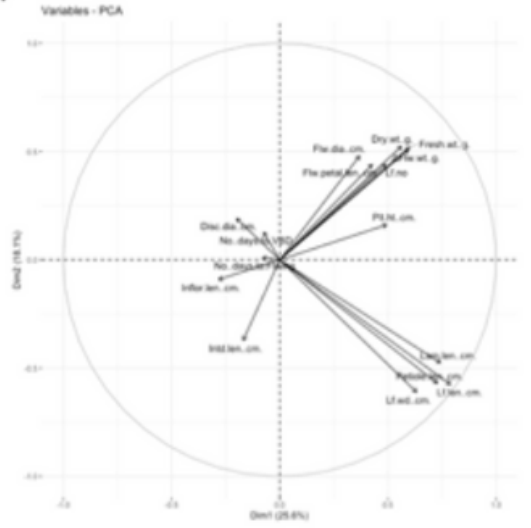

(c)

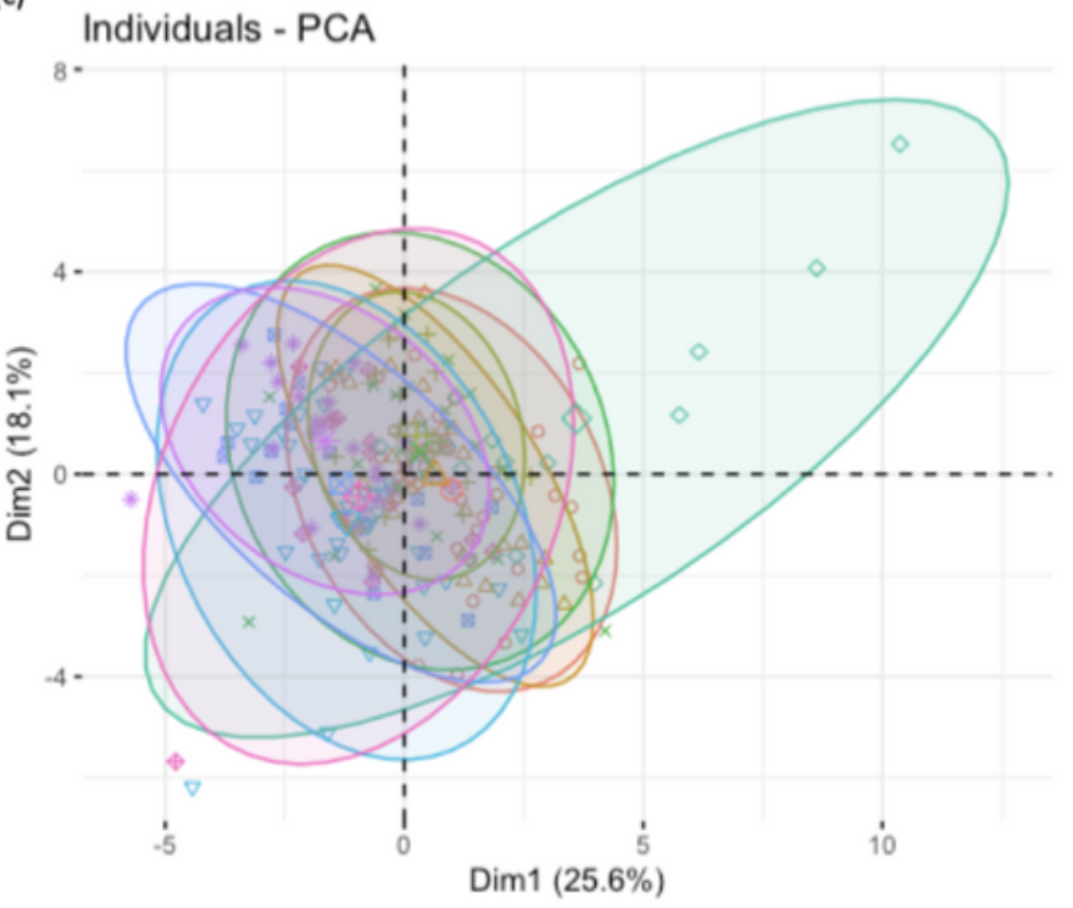

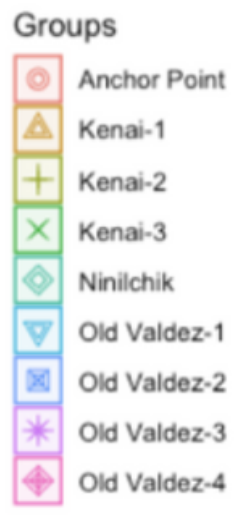




\section{Figure 3}

Chapter 3 Principal components analyses (PCOA) for C. arcticum 16 quantitative morphological traits. (a) Variables plot revealed by two principal components analysis. (b) Scree plot of principal component analysis of C. arcticum populations between eigen value and principal components. (c) Individual scatter plot grouping by populations revealed by two principal components analysis.

(a)

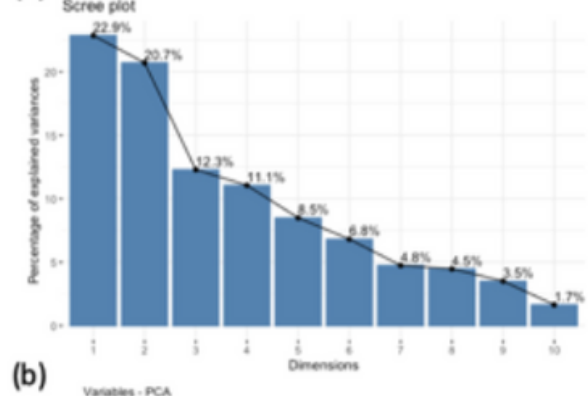

(b)

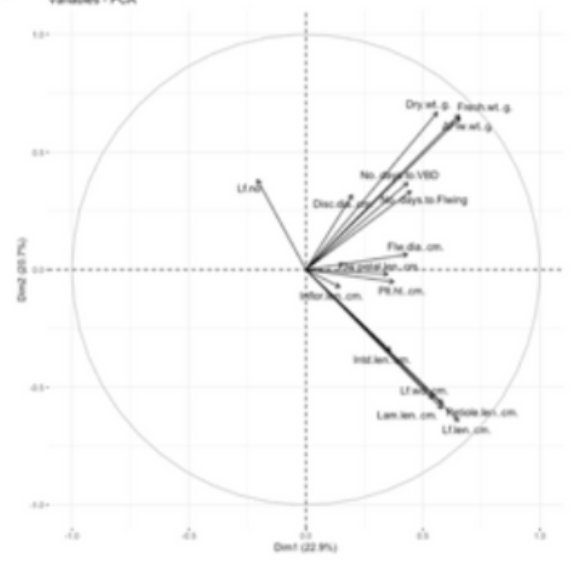

(c)

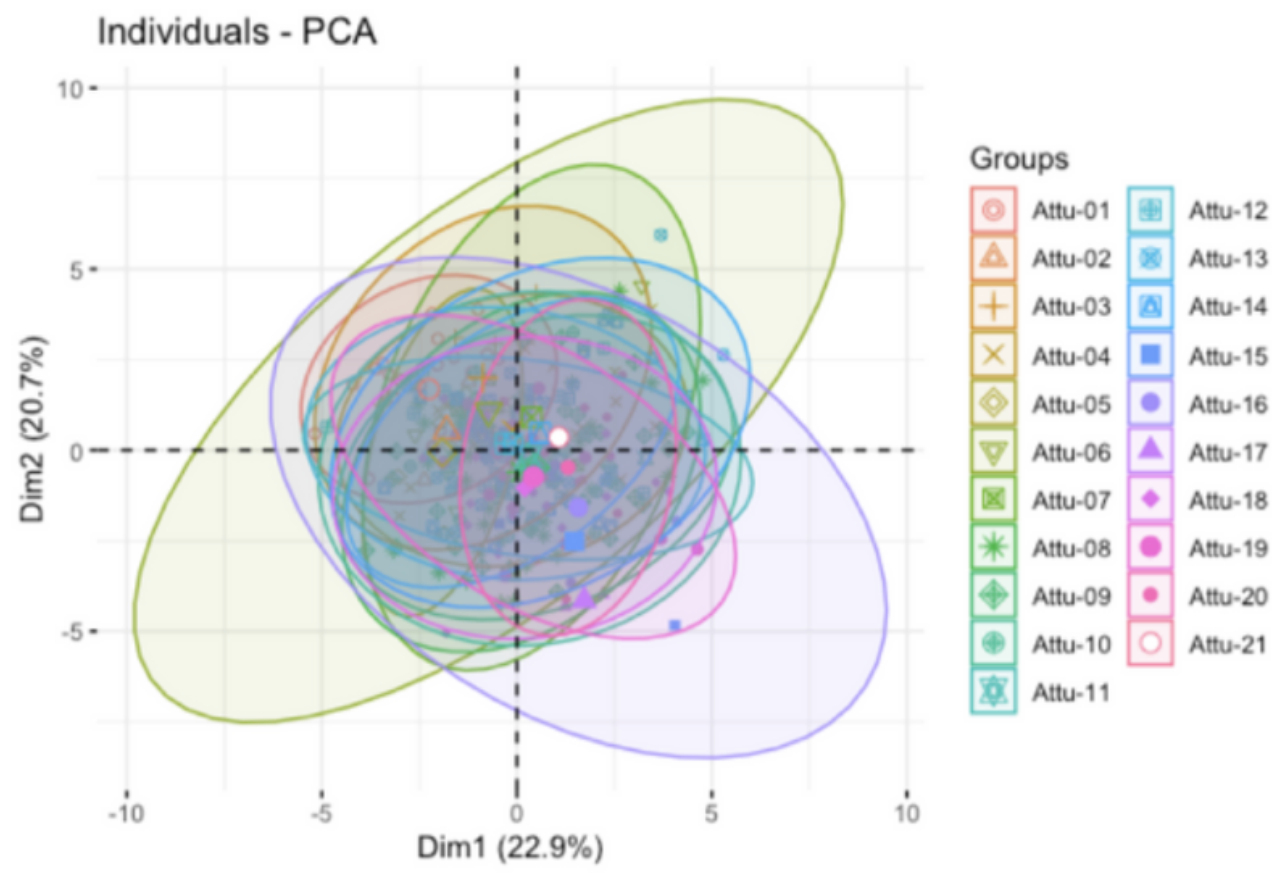

Figure 4

Chapter 3 Principal components analyses (PCoA) for Chrysanthemum arcticum subsp. arcticum 16 quantitative morphological traits. (a) Variables plot revealed by two principal components analysis. (b) Scree plot of principal component analysis of $\mathrm{C}$. a. subsp. arcticum populations between eigen value and principal components. (c) Individual scatter plot grouping by populations revealed by two principal components analysis. 
(a)

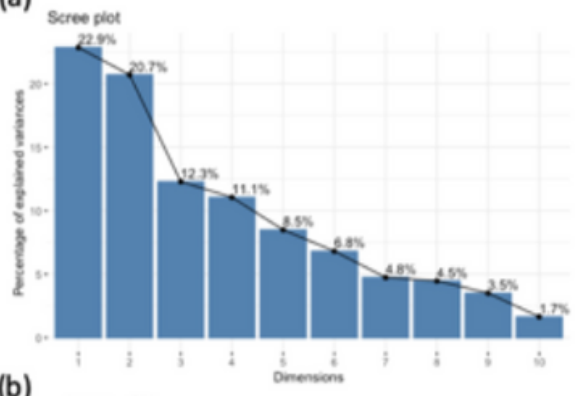

(b)

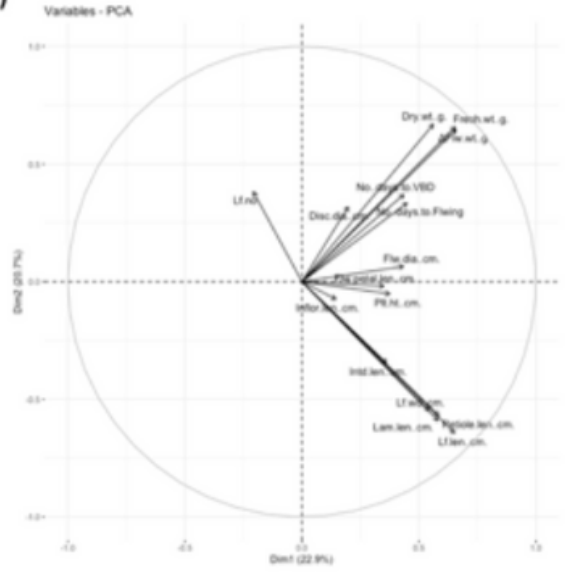

(c)

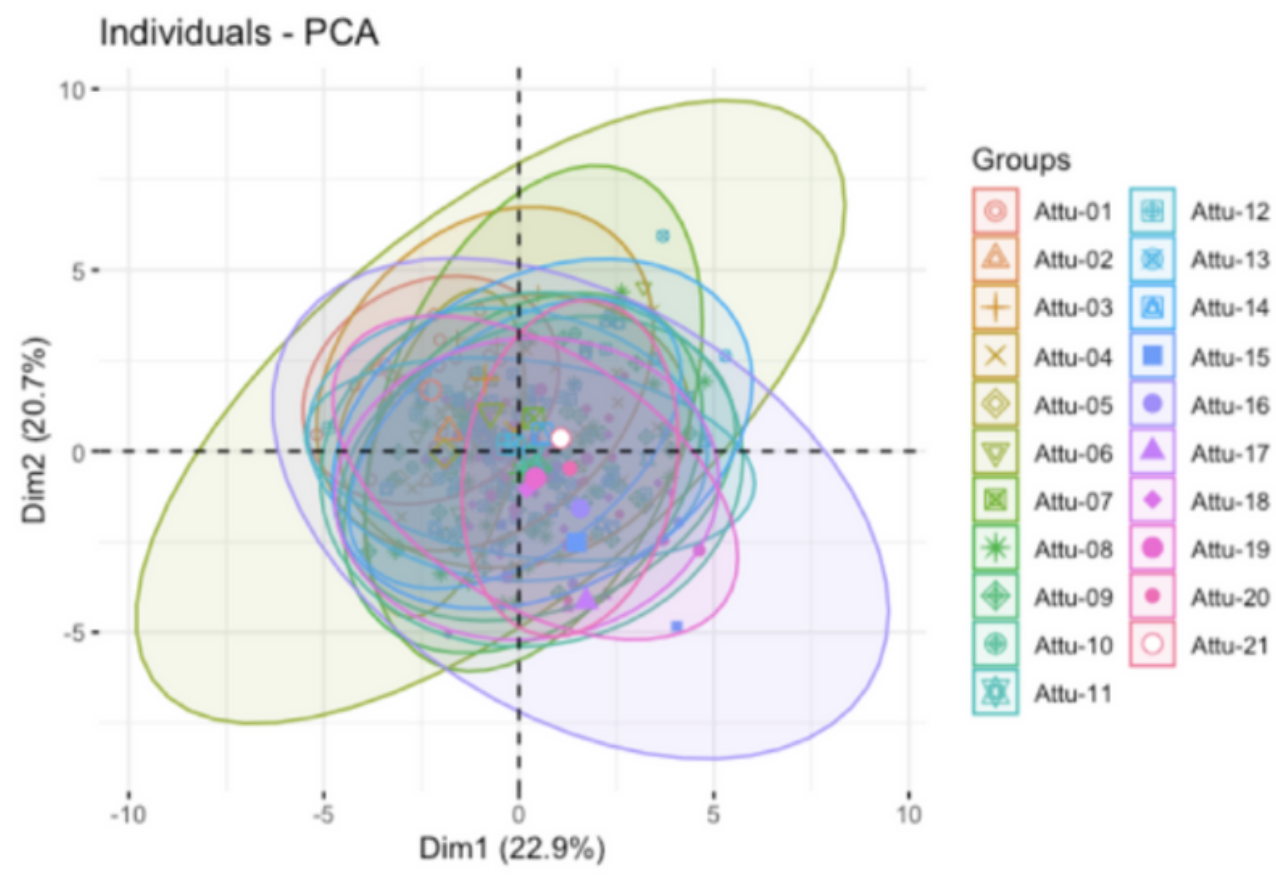

\section{Figure 4}

Chapter 3 Principal components analyses (PCoA) for Chrysanthemum arcticum subsp. arcticum 16 quantitative morphological traits. (a) Variables plot revealed by two principal components analysis. (b) Scree plot of principal component analysis of C. a. subsp. arcticum populations between eigen value and principal components. (c) Individual scatter plot grouping by populations revealed by two principal components analysis. 